IZA DP No. 10227

Are Labor Supply Decisions Consistent with

Neoclassical Preferences?

Evidence from Indian Boat Owners

Xavier Giné

Monica Martinez-Bravo

Marian Vidal-Fernández

September 2016 


\title{
Are Labor Supply Decisions Consistent with Neoclassical Preferences? Evidence from Indian Boat Owners
}

\author{
Xavier Giné \\ World Bank \\ Monica Martinez-Bravo \\ CEMFI
Marian Vidal-Fernández
University of Sydney
and IZA
Discussion Paper No. 10227
September 2016

\author{
IZA \\ P.O. Box 7240 \\ 53072 Bonn \\ Germany \\ Phone: +49-228-3894-0 \\ Fax: +49-228-3894-180 \\ E-mail: iza@iza.org
}

\begin{abstract}
Any opinions expressed here are those of the author(s) and not those of IZA. Research published in this series may include views on policy, but the institute itself takes no institutional policy positions. The IZA research network is committed to the IZA Guiding Principles of Research Integrity.

The Institute for the Study of Labor (IZA) in Bonn is a local and virtual international research center and a place of communication between science, politics and business. IZA is an independent nonprofit organization supported by Deutsche Post Foundation. The center is associated with the University of Bonn and offers a stimulating research environment through its international network, workshops and conferences, data service, project support, research visits and doctoral program. IZA engages in (i) original and internationally competitive research in all fields of labor economics, (ii) development of policy concepts, and (iii) dissemination of research results and concepts to the interested public.
\end{abstract}

IZA Discussion Papers often represent preliminary work and are circulated to encourage discussion. Citation of such a paper should account for its provisional character. A revised version may be available directly from the author. 


\section{ABSTRACT}

\section{Are Labor Supply Decisions Consistent with Neoclassical Preferences? Evidence from Indian Boat Owners*}

This paper studies the labor supply of South Indian boat owners using daily labor participation decisions of 249 boat owners during seven years. We test the standard neoclassical model of labor supply and find that boat owners' labor participation depends positively on expected earnings but also on recent accumulated earnings, albeit weakly. Participation elasticities with respect to expected earnings range between 0.8 and 1.3 and about -0.05 and -0.01 with respect to changes in recent income. While the standard neoclassical model is statistically rejected, it is a good approximation of the labor supply behavior of boat owners in southern India.

\section{NON-TECHNICAL SUMMARY}

Learning about the extent to which the decision of working on a given day depends on the expected wage is crucial to design tax policy. If workers' decision to work is very responsive to higher wages, it would be best to avoid taxing labor income. This is particularly relevant for the economy as labor is an important determinant total production. Answering this question is tricky as in most jobs workers cannot decide which days to work. We use daily data from 249 boat owners in India over several years and find that indeed, higher expected wages (value of catches) on a given is a very strong determinant of deciding whether to go fishing on a given day. In particular, a one percent increase in wages increases the likelihood of going fishing between 0.8 and 1.3 percent. Our findings are consistent with those of taxi drivers, fishermen and stadium vendors in developed countries.

JEL Classification: J22, J31

Keywords: intertemporal labor supply, daily income

Corresponding author:

Marian Vidal-Fernández

School of Economics

University of Sydney

NSW 2006, Sydney

Australia

E-mail: m.vidal-fdez@sydney.edu.au

\footnotetext{
* This paper is a substantial revision of Giné et al. (2010). The first version of paper was circulated in 2009 under the title "Intertemporal Substitution or Reference-Dependent Preferences? Evidence from Daily Labor Supply of South Indian Boat Owners". We thank Kevin Lang, Daniele Paserman, Dilip Mookherjee, Manuel Arellano, Pedro Mira, Iván Fernández-Val, Jordi Jaumandreu, and Marc Rysman for suggestions and discussions. Thanks to participants at the 2009 IZA Summer School in Labor Economics and the Empirical Microeconomics Lunch at Boston University. We are grateful to Felipe Fernández, Rexon Fernando, and Daniel Martínez for their assistance in obtaining international price data. Jiayi Wen and Lisa Oberlander provided excellent research assistance. Monica Martinez-Bravo gratefully acknowledges financial support from Ramón y Cajal Program [RYC-2013-14307]. Marian Vidal-Fernández is grateful to the Fundación Ramón Areces for financial support. The views expressed in this paper are those of the authors and should not be attributed to the World Bank, its executive directors, or the countries they represent.
} 


\section{Introduction}

The estimation of labor supply elasticities plays a critical role in the design of tax policy and transfer programs. An early literature using annual wages and hours worked from salaried workers finds very small wage-elasticities. ${ }^{1}$ These low elasticities could be the result of the limited ability of workers to freely choose the number of hours worked and the fact that wage changes are rarely transitory.

A more recent literature uses data from sectors where workers have discretion over the number of hours worked. By focusing on self-employment occupations (taxi drivers, vendors, etc.), researchers have re-examined whether individuals substitute leisure intertemporally to maximize their overall earnings (see for example, Camerer et al., 1997; Chou, 2002; Farber, 2005, 2008; Fehr and Goette, 2007 and more recently Dupas et al., 2015; Stafford, 2015).

While most of these studies focus on the decision of the choice of hours worked (intensive margin), an alternative and important margin is whether to work at all (extensive margin). In many occupations, individuals cannot decide the number of hours worked due to technological constraints, but they have full discretion about whether or not they work on a particular day. The few studies that have simultaneously analyzed both labor decision margins have typically found much larger labor supply elasticities on the participation margin compared to the hour margin (Heckman, 1993). ${ }^{2}$

While empirically larger in magnitude, the main reason why the extensive margin of labor supply has been understudied is data availability, as most studies only include short employment spells which hinders the ability to study the extensive margin. For instance, the data used by Henry S. Farber in the influential studies on taxi driver behavior in New York City (Farber, 2005, 2008) comprises a non-random sample of the shifts worked. There is limited information on whether drivers worked during the previous days or whether they perceived earnings from alternative occupations. Given the data limitations, Farber restricts attention to the study of the amount of hours worked within a shift. However, he recognizes that a complete analysis of labor supply would need to examine both the hours and participation margins.

In this paper, we use a novel dataset of the daily labor participation of 249 South Indian boat owners during 7 years, which yields over 260,000 boat owner-day observations. Our data

\footnotetext{
${ }^{1}$ See Blundell and MaCurdy (1999) for a comprehensive review of this literature.

${ }^{2}$ Fehr and Goette (2007) find that an experimental wage increase makes Swiss bike messengers sign up for more shifts or days of work, but it also reduces the revenue per shift. The first effect dwarfs the latter so that overall labor supply increases. Similarly, Dupas et al. (2015) find a positive wage elasticity when the measure of labor supply is days worked, but conditional on attending work, the hours-wage elasticity is negative. Using a sample of lobster fishermen in Florida, Stafford (2015) also finds a positive and large wage-participation elasticity and a smaller but still positive wage-hours elasticity.
} 
contains information on complete labor histories of boat owners for an extended period of time. Furthermore, we have detailed information about their socio-economic characteristics and detailed knowledge about their fishing activities. The richness of our data allows us to carefully analyze the extensive margin of labor supply decisions. In particular, and in contrast to most of the previous literature, it enables us to study how past participation decisions and recent earnings affect current labor supply decisions.

Figure 1 reports the probability that boat owners go fishing on a given day of the week, from Monday to Saturday, since all boat owners in the sample rest on Sunday. As we can see from the figure, the probability of working is highest in the beginning of the week and it declines as days go by. Then, on Saturday, it increases again. The figure suggests that there is important variation in labor supply decisions and yet fishing and marketing conditions are similar across days of the week. ${ }^{3}$ Hence, it is likely that the within-week pattern of labor supply is driven by changes in the opportunity cost of fishing across the week. One possible explanation for this pattern is fatigue: since fishing is an onerous activity, boat owners may get tired as they work on consecutive days. This could increase the opportunity cost of their leisure and, consequently, they may decide to take a day off after having worked for several consecutive days. ${ }^{4}$ This behavior would be consistent with standard neoclassical preferences that are non-separable across days because of accumulated fatigue. Alternatively, boat owners may decide not to work later in the week because accumulated earnings early in the week reach a certain weekly income target. As described by Kahneman and Tversky (2000), individuals with reference-dependent preferences experience high (low) marginal utility of income below (above) some income threshold. The likelihood of working for individuals with these preferences decreases discontinuously when the earnings target is achieved.

In this paper we test whether the labor supply of Indian boat owners conforms to the predictions of the standard neoclassical model. Individuals with standard time-separable neoclassical preferences should be more likely to work when earnings are temporarily high. To identify this intertemporal labor supply wage-elasticity we exploit exogenous wage shifters such as the lunar calendar, variation in internationally determined prices of fish, and the price of intermediate inputs (i.e. kerosene). These factors affect the profitability of the fishing activity but, under plausible assumptions, do not affect the opportunity cost of working. Hence, these factors can be used as instruments for the wage and allow the identification of the wage-participation elasticity. ${ }^{5}$

\footnotetext{
${ }^{3}$ See section 2 for further details about the particular context of our study.

${ }^{4}$ The increase in the probability of working on Saturday could be explained by the anticipation of rest on Sunday.

${ }^{5}$ Oettinger (1999) uses a similar methodology to study the labor supply elasticity of stadium vendors. He uses predictors of high game attendance as shifters of the profitability of working as a stadium vendor.
} 
In addition, we study whether the labor supply decisions are affected by across-days preference spillovers. First, the richness of our data allows us to proxy for the opportunity cost of leisure using the number of prior consecutive days that the boat owner worked. Second, we test whether labor supply decisions depend on recent accumulated earnings. This dependency would be at odds with the assumption of standard time-separable neoclassical preferences. ${ }^{6}$

Our main results are as follows. First, we find that boat owners' labor participation depends positively on expected earnings. Our estimated intertemporal elasticities are significantly positive and range between 0.8 and 1.3 when evaluated at mean characteristics. As expected, and predicted by neoclassical preferences, boat owners are more likely to fish when they expect higher earnings. This indicates that boat owners are willing to substitute labor inter-temporally in order to maximize their overall earnings. These estimates are slightly larger than those of stadium vendors, estimated by Oettinger (1999), which range between 0.55 and 0.75. They are similar than those of Swiss bike messengers across worked shifts in Fehr and Goette (2007) estimated between 1.12 and 1.25 and those of lobster fishermen in Florida estimated in Stafford (2015) ranging from 1.05 to 1.26. ${ }^{7}$

Second, we find that boat owners' labor participation depends negatively on recent accumulated earnings. The effects are statistically significant and robust across a number of specifications. However, the magnitude of the effect is small: the estimated elasticities with respect to cumulative earnings are between -0.05 and -0.007 . These short-term income effects are between 1 and 4 percent of the magnitude of the response to changes in expected earnings.

The fact that recent earnings matter (albeit weakly) is inconsistent with neoclassical preferences but consistent with reference-dependent preferences with a the target set on a weekly, rather than daily basis. When boat owners go fishing, they leave the shore around the same time, travel to a catchment area, cast and collect the nets, and return to the shore in the morning in time to sell the catch. There is no adjustment possible in the hours margin.

\footnotetext{
${ }^{6}$ Note that another reason why labor supply decisions may present across-days spillovers is the presence of imperfect credit markets. The presence of imperfect credit markets could generate liquidity constraints, which in turn, could generate a dependency between labor supply and recent earnings. Intuitively, a good day of fishing would relax the liquidity constraint and could induce the individual not to work (Rossi and Trucchi, 2016). However, boat owners in our sample have substantial access to credit and savings technologies. They market their daily catches using middlemen and fishery societies that extend short and long term credit. Hence, the assumption that boat owners are able to smooth consumption across-days of a week seems highly plausible in our context. See section 2 for a more detailed discussion.

${ }^{7}$ Our participation elasticities are also much larger than those in Goldberg (2016) estimated at 0.15. We believe that this is driven by the particular context of her study. Goldberg (2016) conducted a field experiment in Malawi where she ran a workfare-type program once a week varying the wage offered to laborers randomly. The reason why estimated elasticities are lower could be due to the fact that the experiment was run during the lean season when the opportunity cost of labor is low and thus labor supply is fairly inelastic.
} 
When asked about targets, most boat owners report having a weekly target (rather than a daily target). While the nature of this weekly target is unclear, most boat owners report targets that are similar to their average weekly catches. This suggests that the weekly target may be a proxy of their income expectations, consistent with the work of Köszegi and Rabin (2006), and not based on a minimum income needed for weekly expenses.

Previous studies that have analyzed whether hourly labor supply decisions are consistent with reference-dependent preferences have found mixed results. Camerer et al. (1997) was the first study to provide suggestive evidence in support of this hypothesis. They found that New York City taxi drivers work fewer hours on days with higher wages. Their econometric model and results were later disputed by Oettinger (1999) and Farber (2005). ${ }^{8}$ In contrast, Farber (2005) found that the probability to stop working depends on cumulative hours worked on that day, but not on cumulative earnings, hence, at odds with the reference-dependent preferences assumption. However, Farber (2008) implemented a maximum likelihood estimation strategy allowing income targets to vary by taxi driver and shift. Farber estimated a substantial increase in the probability of stopping once the target was reached. More recently, Dupas et al. (2015) find that the probability that Kenyan bicycle taxi drivers stop working increases once they raise enough daily income to reach their self-reported cash needs for the day. ${ }^{9}$

The paper closest to ours is Stafford (2015). She studies both the intensive and extensive margins of labor supply of fishermen in Florida. Her study shows that failing to control for self-selection in the participation margin, wage endogeneity and measurement error can lead to downward biased estimates. Our participation and earnings data come from administrative records and are thus less subject to measurement error. In addition, while our participation elasticities are somewhat lower than those in Stafford (2015), survey data can explain the differences in estimates. In particular, boat owners in our sample are the main income earner in the household and their spouses make money selling the fish that their husbands are unable to sell to merchants in the local fish market. Boat owners thus behave more like single individuals than married individuals, which could explain the lower elasticities that we find. ${ }^{10}$ Unlike Stafford (2015), our analysis includes the possibility of

\footnotetext{
${ }^{8}$ Farber (2005) argued that the specification of Camerer et al. (1997) suffered from downward division bias because log hours worked on a given day were regressed on log hourly wage, computed by dividing daily earnings by the reported number of hours worked that day. Oettinger (1999) argued that daily wage fluctuations in Camerer et al. (1997) might also have been driven by changes in total labor supply of taxi drivers, hence, leading to inconsistent estimates of the labor supply elasticity due to the wage endogeneity.

${ }^{9}$ Other papers that have tested the hypothesis of reference-dependent preferences are, Abeler et al. (2011); Crawford and Meng (2011); Fehr and Goette (2007).

${ }^{10}$ The literature suggests that labor elasticities are larger for married individuals than single individuals, presumably because household bargaining allows couples to take advantage of temporary increases in the wage rate.
} 
across-days preference spillovers. In particular, we provide evidence that recent earnings are negatively correlated with participation, which is suggestive of the existence of a weekly target on catches. Finally, Stafford (2015) looks at fishing in a highly regulated environment such as Florida, while we look at fishing in a developing country with few and weakly enforced regulations.

Other recent contributions to the literature are Goldberg (2016) and Dupas et al. (2015). These papers implement field experiments to study labor supply decisions also in developing countries. Our context is however different from theirs. Subjects in these experiments had limited access to credit and insurance markets and the study period lasted only several weeks. In addition, Goldberg (2016) cannot study the impact of consecutive days of work nor the impact of recent earnings because individuals are only offered work once a week. In our context, temporary increases in earnings are uncorrelated with effort, but in Dupas et al. (2015) higher expected earnings come from a larger expected number of trips rather than an increase in the hourly rate, and thus higher expected earnings are always associated with higher expected effort.

Our paper contributes to this literature by providing evidence that the standard neoclassical model is statistically rejected, since recent earnings are negatively correlated with labor participation. However, the low relative magnitude of these effects suggests that the neoclassical model is still a good approximation of the labor supply behavior of boat owners in coastal southern India.

The rest of the paper is structured as follows. Section 2 describes the institutional environment and data used. Section 3 describes the conceptual framework and empirical strategy. Section 4 discusses the results, Section 5 reports robustness checks and finally Section 6 provides some discussion and concluding remarks.

\section{Background and Data}

We use a sample of 249 boat owners from seven villages along the coast of the southern region of the Gulf of Bengal in the state of Tamil Nadu. Figure 1 illustrates the exact location of these villages. $^{11}$

Boat owners belong to a Catholic fishing community, which following the precepts of their religion, usually work from Monday to Saturday and rest on Sunday to attend mass. On a typical night, boat owners go to sea around 1 A.M. together with a crew of three or four laborers. Before leaving, each boat owner decides the location and the type of fishing nets to

${ }^{11} 29$ boat owners are located in the village of Idindakarai, 24 in Kootapanai, 15 in Manapad, 50 in Patnam, 41 in Periyathalai, 27 in Thomayar Puram, and 63 in Uvari. 
carry according to the type of fish expected. Fishing locations are anywhere between one and three hours from the shore. Nowadays boat owners use GPS devices to track the location. For this reason, it is the boat owner who is in charge of deciding whether and where to go fishing and of piloting the outboard engine to the location. Once the location is reached, the crew cast the nets, wait for a few hours and collect them, drawing in their catches. The amount of catches depends on several factors including, the boat owner's experience in selecting a good location, the laborers' strength and ability in pulling the nets and separating the fish, weather conditions, and luck.

Around 7 A.M. they head back to the beach, where every boat owner sells his catch to a middleman (or his society) who markets the catches to multinational fish-processing companies. Examples of the type of fish and seafood traded are sardines, tunas, cephalopods, crabs, and lobsters. The fish that are too small under international legal minimum size standards are sold at the local market for a lower price.

All boat owners, except those from Patnam village, belong to a fishermen's society with over 7,000 members spread over the districts of Tirunvelli and Tuticorin. Although this society has been growing in membership in the area, it does not yet operate in Patnam, a village that is located further north.

Both the society and middlemen in Patnam lend money to boat owners for equipment (purchase of the boat, gear, repairs etc.) as well as for consumption needs. ${ }^{12}$

Boat owners typically keep 50 percent of the value of catches after kerosene expenses and commissions paid to the middlemen or society, and the rest is evenly divided among laborers. ${ }^{13}$ While kerosene usage depends on the travel time to the fishing location, the "take-home" earnings of boat owners is roughly proportional to the value of catches.

\subsection{Determinants of Catches}

Boat owners' daily earnings depend on the price and quantity of fish. In South India, boat owners, middlemen and societies are all price takers. The catches are bought by exporting and processing companies that buy 45 different fish species at internationally-determined market prices that depend on the season and type of fish.

\footnotetext{
${ }^{12}$ In exchange for marketing and credit services, middlemen and the society keep a commission of seven percent of daily sales. In addition, they keep ten percent of the value of total catches, which they deduct from the principal owed by the boat owner. Finally, another three percent is automatically placed into a savings account and refunded to the boat owner in December for the celebration of Christmas and the New Year. Boat owners who belong to the society also contribute one percent of their daily earnings to a pension fund, and two percent for life insurance and the society's administrative costs.

${ }^{13}$ Laborers are promised at least a daily wage of approximately INR 100. If their individual share from the value of catches is higher than INR 100, they keep the share, otherwise they earn the promised minimum wage. Only in few occasions of very poor catches do laborers earn the minimum wage.
} 
In terms of catches, boat owners reported in a survey conducted in 2007 that the main factors are the season, weather conditions, and the lunar calendar. Consistently, a voluminous literature in natural science and land economics (for example Smith, 2002; Smith and Wilen, 2005, and Watson and Pauly, 2001) supports the hypothesis that weather conditions, expertise - the knowledge of when and where to catch a particular type of fish - and luck are the main factors affecting the volume of catches.

Boat owners obtain daily weather forecasts from the radio and TV and are therefore aware of weather conditions when deciding whether and where to go fishing.

In addition, there is some evidence from the biology literature that lunar phases affect fish abundance. Some authors suggest that the correlation is due to night brightness. For example, Luecke and Wurtsbaugh (1993) state that when there is a full moon in Utah, lake fishes stay in deeper areas to hide from detection of potential predators. However, the most supported hypothesis is that lunar phases affect fish behavior via migratory patterns and reproduction cycles. ${ }^{14}$ Biologists argue that the reason for such patterns is the existence of positive externalities in breeding and egg protection when fish synchronize their reproduction cycles, which happen to follow lunar periods.

\subsection{Data and Descriptive Statistics}

We use several data sources in the analysis. First, from the middlemen and societies we use hand-written records of all sales and loan transactions. At the end of each year, they provide a copy of individual sales records to each one of their boat owners. Each boat owner thus has a precise record of his catches. These are the records we use in our analysis from January 2001 to July 2007, yielding a total of about 260,000 observations.

Unfortunately, neither the middlemen, societies nor boat owners keep track of the prices paid by the exporting and processing companies. Since frozen fish is sold internationally, however, the exchange rate and the international price of Indian fish should be relatively good proxies for the actual price boat owners receive for their catches.

We therefore collected price data from one of the largest fish markets in Europe. Spain has the largest fish trading companies in the continent and receives the majority of the fish that is later redistributed to the rest of Europe. The largest Spanish fish market, Mercabarna, provided us with all available information on Indian fish imports. Because they only keep records of fish species that are consistently traded for at least a year and with significant total sales, they provided us with records on the average price at which frozen Indian calamari is sold to retailers, which corresponds to the largest share of Indian sea product traded in the

\footnotetext{
${ }^{14}$ See, for example, Robertson et al. (1990), Tesch (1989), Barlow et al. (1986), Hastings (1981), Entright (1975), and Zucker (1978).
} 
Spanish fish market. ${ }^{15}$ Price data are daily for 2006 and 2007 and weekly during the period 2001-2005. Probably because the calamari is frozen and it can be stored, these prices do not vary significantly within a week and sometimes remain constant even within a month. ${ }^{16}$

In addition, boat owners and their wives were surveyed in 2005 and 2007. The survey included questions on a wide variety of topics, such as socio-demographic characteristics, other sources of income, inventory of assets, income shocks, and savings along with a module about income targets.

We also collected data on the determinants of catches, including daily weather data from the closest Indian Meteorological Department station in Tuticorin, a town located approximately 20 kilometers away from the closest village, as depicted in Figure 2.

Finally, we collected data on the price of kerosene. Time series data on local prices are not available and so we rely on the real daily price at which kerosene is traded in Singapore, the closest international fuel market. ${ }^{17}$

Table 1 depicts boat owners' descriptive statistics using 2007 survey data. On average, boat owners are 42 years old, have approximately 5.6 years of education, and live with four other household members. Since all are married, one of their family members is their wife. In most cases, the other relatives are children, but few boat owners have extended family members living with them, such as in-laws, parents, or siblings. In all households, the boat owner's earnings are the main source of income. However, there is usually another family member who works as well, typically their spouse, selling the fish in the local fish market that their husbands are unable to sell to merchants.

Boat owners' daily gross average earnings are INR 1,076. Since the survey includes a few questions about the amount of their daily expenses on kerosene and laborers' wages, we can get a rough estimate of their net daily income at INR 310 (roughly USD 6.50). Boat owners go fishing 73 percent of week days excluding Sundays or approximately 4 days a week. $^{18}$ In the analysis of Section 4 we use three different samples of boat-owner-weeks. The first (baseline sample) corresponds to all boat-owner-weeks when the boat owner went fishing at least one day during that week. ${ }^{19}$ The second corresponds to all boat-owner-weeks

\footnotetext{
${ }^{15}$ They did not keep track of prices for other types of Indian fish because according to Mercabarna, the volume of trade was not significant enough.

${ }^{16}$ Fish Information and Services (FIS), a widely recognized consulting firm for global seafood industry information, reported that the vast majority of exported Indian fish (calamari, octopus, and cuttlefish) is sold in Europe. The rest of the exports, consisting mainly of tuna, is exported to East Asia and particularly Japan. (We tried to collect price data but we were unsuccessful.)

${ }^{17}$ Sources: US Energy Information Administration (fuel prices) and International Monetary Fund (Consumer Price Index and Exchange Rate).

${ }^{18}$ The following days are considered holidays: the first Friday of every month, January 1st and 6th, Good Friday (during Easter), August 15th (Independence Day), December 3rd, 21st and 25th.

${ }^{19}$ Sundays are excluded because there is no fish market and boat owners never go fishing. The sample also
} 
when the boat owner went fishing at least three days during that week. This latter sample restriction further excludes periods of absence from the labor market due to sickness or some other special temporary condition that interferes with boat owners normal labor market participation. Our third sample is even more restrictive and focuses on weeks when boat owners were active at least for four days. All these samples exclude extended absences from fishing due to temporary migration or long periods of inactivity. Note that the samples are unbalanced because individuals become boat owners at different points in time. In addition, the samples exclude boat-owner-weeks with missing participation data, so that all boat-owner-weeks have participation data for all 6 working days. ${ }^{20}$

Perhaps due to their access to credit, average savings (in bank deposits, cash at home, jewelry and other forms of savings) appear low at INR 2,840 which is less than the average value of catches for two days.

Table 2 shows descriptive statistics for the variables that affect boat owners' value of catches. During 2001-2007, the average price of frozen Indian calamari at the Spanish market stays stable around EUR 3 per kilogram, and the Real Exchange Rate INR-EUR is 4 on average. $^{21}$ Finally, the real price at which a gallon of kerosene is exchanged in the Port of Singapore - the main center of fuel exports to the rest of Asia - is approximately INR 63 (USD 1.2) per gallon, and unlike the price of calamari, it fluctuates considerably, with a variance of 21.7 .

\section{Conceptual Framework and Empirical Strategy}

\subsection{A Model of Boat Owner Labor Supply}

Every day, boat owners decide whether to go fishing or not, considering their expected catches, their level of fatigue, and, possibly, the cumulative catches they have obtained during that week. A full description of their optimal decision requires solving a stochastic dynamic programming problem. Instead, we follow the approach of Farber (2005) and discuss a static approximation of the optimal decision problem.

excludes the period between December 26th of 2004 and February 17th of 2005 which coincides with the aftermath of the 2004 Indian Ocean tsunami.

${ }^{20}$ For the median boat owner, we drop 8 percent of the weeks due to first sample restriction (going fishing at least one day of that week). When restrict the sample to weeks when boat owners are active for 3 and 4 weeks, we eliminate 20 and 30 percent of the original sample, respectively.

${ }^{21}$ The Real Exchange Rate (RER) is $\mathrm{RER}=\mathrm{e}_{\mathrm{r} / \mathrm{e}}{ }^{*}\left(\mathrm{P}_{\mathrm{e}} / \mathrm{P}_{\mathrm{i}}\right)$, where $\mathrm{P}_{\mathrm{e}}$ and $\mathrm{P}_{\mathrm{i}}$ are the Current Price Indexes (CPI) in Europe and India respectively. RER and kerosene prices use 2007 as base year. Sources: International Monetary Fund (CPI), European Central Bank (ER) and US Energy Information Administration (Kerosene prices). 
Consider a boat owner that on day $t$ derives utility from consumption $x_{t}$ and leisure $l_{t}$. Leisure takes value 0 if the boat owner decides to work and 1 if he decides to stay at home. Thus, the daily utility function is

$$
u_{t}=a\left(x_{t}\right)+b\left(l_{t}\right)
$$

The intertemporal utility function is given by

$$
U=\sum_{t=0}^{T} \rho^{t}\left(a\left(x_{t}\right)+b\left(l_{t}\right)\right)
$$

where $\rho$ is the discount factor. Notice that, with this simple specification, we assume that the utility function is time-separable and the individual does not have reference-dependent preferences, hence, representing the standard neoclassical preferences.

If the boat owner decides to go fishing he receives a net wage of $w_{t}$. The intertemporal budget constraint of the individual assuming access to perfect credit markets is

$$
\sum_{t=0}^{T}(1+r)^{t} w_{t} l_{t}=\sum_{t=0}^{T}(1+r)^{t} x_{t}
$$

where $r$ is the interest rate.

It is straightforward to show that the optimal labor participation decision is given by the following expression

$$
l_{t}^{*}=\left\{\begin{array}{l}
0 \text { if } w_{t} \geq \frac{b^{\prime}\left(l_{t}\right)}{a^{\prime}\left(x_{t}\right)} \\
1 \text { if } w_{t}<\frac{b^{\prime}\left(l_{t}\right)}{a^{\prime}\left(x_{t}\right)}
\end{array}\right.
$$

where $w_{t}$ is the wage of the day. Implicitly, we assume that boat owners have perfect foresight of future wages. In the empirical application, we will instrument wages using factors that can affect the wage predictions of boat owners.

This simple model of labor supply predicts that, when individuals have time-separable neoclassical preferences, their decision of working on a particular day is only influenced by their expected wage for the day and the marginal rate of substitution between consumption and leisure. The model thus makes the following predictions:

1. The likelihood of working is increasing in the expected wage.

2. The likelihood of working is decreasing in the marginal utility of leisure.

3. The likelihood of working is unrelated to the value of cumulative earnings in previous days. 
The first prediction implies that, in days when fishing is highly profitable, labor participation will be higher. The reason is that it is optimal for individuals to intertemporally substitute leisure in order to maximize their overall earnings. In our data we have information on the realized value of catches, which is a proxy for the net wage of boat owners. However, since earnings are also affected by the labor supply decisions, we instrument this variable using exogenous demand factors.

The second prediction states that participation is less likely when the opportunity cost of fishing is higher. One specific factor that can affect the marginal utility of leisure is the level of fatigue. In the empirical application, we proxied the level of fatigue by the number of cumulative days the individual has hitherto worked. Because fishing is an onerous activity, it is likely the more consecutive days the boat owners has been fishing, the more tired they become.

The third prediction constitutes our main test of the reference-dependent preferences. If boat owners have neoclassical preferences with time-separable utility and access to perfect credit markets, then the amount earned in prior days should not affect their decision of going fishing. If instead boat owners have a level of income they aim to achieve, e.g. a weekly target income, we expect to find a lower probability of going fishing, the higher the cumulative catches in the previous days.

\subsection{Empirical Model for the Estimation of Labor Supply}

The empirical predictions described in the previous subsection suggest the estimation of the following latent model of labor force participation:

$$
\begin{aligned}
P_{i t} & =\mathbf{1}\left(P_{i t}^{*}>0\right) \\
P_{i t}^{*} & =\alpha \ln \left(w_{i t}^{e}\right)-C_{i t}+e_{i t} \\
& =\alpha \ln \left(w_{i t}^{e}\right)-X_{i t} \gamma-\theta_{i}+\beta \ln \left(\widetilde{w}_{i t}\right)+e_{i t},
\end{aligned}
$$

where $P_{i t}$ is a dummy variable that takes value one if boat owner $i$ goes fishing at date $t$, and zero otherwise. It is optimal for the boat owner to go fishing when the expected wage $w_{i t}^{e}$ is sufficiently high, relative to the the opportunity cost of working, captured by $C_{i t}$ plus some random utility shock $e_{i t}$. We represent the opportunity cost of working as the sum of three components: $X_{i t}$ contains variables that affect the marginal utility of leisure, such as, day of the week dummies, holiday dummies, a full set of month-year interactions, measures of weather conditions, dummies for the number of consecutive days worked, and days of the week interacted with the number of family members of the boat owner. All these are factors 
can affect the boat owner utility of leisure, since boat owners might prefer to stay at home during holidays, when the weather conditions are particularly harsh, or when they have been working for several consecutive days. The second component, $\theta_{i}$, corresponds to boat owner fixed effects. This set of dummies captures idiosyncratic differences in the dis-utility of working of boat owners, as well as any other time-invariant characteristics. The third component, $\ln \left(\widetilde{w}_{i t}\right)$, corresponds to the log of the cumulative wage earnings in the previous days of the week.

By estimating the parameters $\alpha, \gamma$ and $\beta$, we can assess the validity of the empirical predictions described in the previous subsection. In particular, if we find that $\alpha>0$ and $\beta=0$ the behavior of boat owners would be consistent with neoclassical, time-separable preferences described in Equation 2. Furthermore, $\alpha>0$ would suggest that boat owners intertemporally substitute labor across periods in order to maximize their overall earnings. If $\beta<0$, the behavior of boat owners is at odds with the time separability assumption. Furthermore, note that in the specification we control by the number of consecutive days worked. Hence, if after controlling flexibly by the level of fatigue, we observe recent cumulative earnings negatively affecting the likelihood of participation, the evidence will be suggestive of the existence of reference-dependent preferences: the higher level of cumulative earnings for the week, the higher the likelihood that the weekly target is achieved and, hence, the lower the likelihood of working in a given day.

Under the assumption that the error term is normally distributed and that realized wages are exogenous, the econometric model in (7) could be estimated by a reduced-form probit specification where realized wages are used instead of expected wages. However, the realized wages are determined in equilibrium and, hence, potentially affected by labor supply decisions. Following Oettinger (1999), we use exogenous demand shifters to instrument for realized wages.

The estimation proceeds in several steps. First, we specify the following reduced form wage equation:

$$
\ln \left(w_{i t}\right)=Z_{i t} \delta+\mu_{i}+u_{i t}
$$

where $Z_{i t}$ includes observable predictors of earnings, $\mu_{i}$ are a set of boat owner fixed effects and $u_{i t}$ is an error term. It is useful to decompose the set of predictors included in $Z_{i t}$ in two sets of variables. First, $Z_{i t}$ includes factors that affect predicted earnings, but could also affect the opportunity cost of fishing. Those variables are measures of weather conditions, day of the week dummies, holiday dummies, the cumulative value of catches within the week, and a full set of month-year interactions. ${ }^{22}$ These variables are included both in the earnings

\footnotetext{
${ }^{22}$ The value of cumulative catches within a week is a predictor of current catches because the amount of fish is serially correlated. We present evidence of this below.
} 
equation (Equation 8), and in the structural participation equation (Equation 7).

The second set of variables included in $Z_{i t}$ affect predicted earnings, but should not affect the opportunity cost of fishing. These variables are the price of kerosene, the international price of frozen calamari, the INR-EUR exchange rate, and dummies for the phase of the moon calendar. As discussed in the background section, these variables affect the profitability of the fishing activity, hence the net wage of boat owners. However, it is unlikely that they also affect the labor participation decisions by influencing the opportunity cost of working. These variables are excluded from the participation equation (Equation 7) and, hence, are arguably valid instruments of the wage of boat owners. ${ }^{23}$

The estimation of the reduced-form earnings equation requires adjusting for self-selection, since we only observe the earnings of boat owners on the days they decide to work. ${ }^{24}$ We apply a two-step Heckman procedure to the estimation of Equation 8 to correct for selection bias. We first estimate a reduced-form probit model for the participation decision that allows us to estimate the inverse Mills ratio. Then, we proceed to estimate the log earnings equation (Equation 8) including the inverse Mills ratio as an additional regressor. As shown by Heckman (1976), this procedure corrects for the selection bias. The inverse Mills ratio is identified as long as some of the variables that affect the opportunity cost of working, and hence included in the reduced-form participation model, are excluded from the earnings equation. We assume that the number of consecutive days worked and the days of the week interacted with the number of children can be excluded from the earnings equation. ${ }^{25}$ See Table 3 for a summary of the variables included in each specification.

Finally, the estimation of the earnings equation allows us to obtain the predicted earnings for the uncensored sample of boat owners. We then estimate the structural probit equation (Equation 7) using the predicted earnings instead of the expected earnings. This procedure allows us to consistently estimate the structural parameters of interest and to provide estimates of wage-labor supply elasticities.

\footnotetext{
${ }^{23}$ See Section 5 for further discussion on the validity of these variables as instruments and for additional robustness checks.

${ }^{24}$ If there exists unobserved time-varying elements that jointly affect participation and earnings, expected log earnings conditional on participation are:$$
E\left(\ln \left(w_{i t}\right) \mid X_{i t}, \ln \left(\widetilde{w}_{i t}\right), Z_{i t}, \mu_{i}, P_{i t}=1\right)=Z_{i t} \delta+\mu_{i}+E\left(u_{i t} \mid u_{i t}+e_{i t} \geq X_{i t} \gamma-\beta \ln \left(\widetilde{w}_{i t}\right)-Z_{i t} \delta+\theta_{i}-\mu_{i}\right)
$$

where the last term represents the bias induced by self-selection.

${ }^{25}$ While the opportunity cost of working might be very different for boat owners that have more children, it is unlikely that this affects their expected earnings. Similarly, the number of cumulative days worked can affect the marginal utility of leisure, but it is unlikely to affect the earnings potential of boat owners.
} 


\section{Results}

\subsection{Reduced-Form Participation Equation}

Before turning to the estimation of the structural participation model, we estimate a reducedform model of participation. More specifically, we estimate a probit model where the participation dummy is regressed on all the exogenous regressors, including those that affect participation through its influence on the opportunity cost of working, $X_{i t}$, and those that affect participation through the expected wage, $Z_{i t}$. Although this model does not allow us to recover the structural parameters of interest, it constitutes a first step towards assessing which variables are relevant for the participation decision. Furthermore, this reduced-form model constitutes the first stage of the Heckman two-step procedure to correct for sample selection of the earnings equation.

Table 4 presents the results. Panel A shows the point estimates of a selected set of regressors. Due to space constraints, Panel B only shows the p-values of the joint significance of a set of additional regressors, including a full set of boat owner fixed effects. ${ }^{26,27}$

In Column 1 the reduced form probit is estimated in our baseline sample. Columns 2 and 3 further restrict the sample to weeks when the boat owner participates at least 3 and 4 days of the week, respectively. The table presents standard errors clustered at the month-boat owner level in parenthesis. ${ }^{28}$

The results show that the log of the cumulative catches within the week is a postivie predictor of participation in the baseline sample (Column 1), but it is a negative predictor when we restrict the sample to weeks of substantial labor force participation (columns 2 and 3). This instability in the coefficients could be driven by the fact that in this reduced-form specification, cumulative catches could affect participation through different channels. On the one hand, they could affect the opportunity cost of working if individuals have referencedependent preferences. On the other hand, cumulative catches could be correlated with expected earnings in the current period: catches are serially correlated across time since a day of good catches is typically preceded by another day of good catches. Restricting the sample to weeks with sufficient participation seems to reduce the serial correlation effect.

The next set of regressors correspond to variables that we hypothesize only affect participation through expected earnings. The coefficients on this reduced-form probit are consistent with our priors. A higher value of the rupee, a lower price of kerosene, a higher price of cala-

\footnotetext{
${ }^{26}$ See Appendix Table 1 for the complete set of estimates of the reduced-form probit specification.

${ }^{27}$ Since the average number of observations per individual is around 1,000, the bias from the incidental parameters problem in our probit estimates discussed in Chamberlain (1980) is negligible.

${ }^{28}$ Clustering our standard errors at the boat owner level does not affect our results.
} 
mari, and the first and last quarter moon phase typically lead to higher expected earnings. The results show that indeed, these factors are associated with a higher probability of participation.

The last set of regressors displayed in Panel A correspond to dummies for one consecutive day worked and a dummy for two or more consecutive days worked. ${ }^{29}$ The estimates in Column 1 suggest that the higher the number of consecutive days worked, the more likely is that the boat owner goes fishing. However, as can be seen in columns 2 and 3, the consecutive days dummies exhibit a different pattern when the sample is restricted to boat-owner-weeks of substantial labor force participation. In this case, labor force participation in previous days is associated with lower probability of working. This is consistent with fishing increasing the fatigue of boat owners and, all else equal, making participation less likely. As discussed below, a similar pattern emerges when focusing on the structural participation probit model. This change in the pattern of coefficients when we restrict the sample is consistent with the baseline sample including weeks when boat owners are not able to work because of sickness or another reason. For this reason, our preferred samples focus on weeks with sufficient labor force participation.

Panel B displays the p-values for tests of joint significance of additional sets of controls, which include measures of weather conditions, dummies for the different days of the week, a full set of month-year interactions, dummies for national and religious holidays, and dummies for the days of the week interacted with the number of family members. As we can see, all of these groups of controls are statistically significant.

\subsection{Earnings Equation}

Table 5 presents the estimates of the log-earnings equation (Equation 8), when we correct for the self-selection of the sample of boat owners. In particular, all specifications include as a regressor the inverse of the Mills ratio estimated in the corresponding column of Table 4. The coefficient on the inverse of the Mills ratio, $\rho$, is included at the bottom of Table $5 .{ }^{30}$

The inverse of the Mills ratio is identified by the exclusion in the earnings equation of variables that are included in the reduced-form participation equation. These variables are the dummies for the number of consecutive days worked and day of the week dummies

\footnotetext{
${ }^{29}$ Alternative specifications of the number of days worked do not affect the results. We chose the current specification because individual dummies for two or more consecutive days worked are not statistically different from one another.

${ }^{30} \mathrm{We}$ note that standard errors are not adjusted to account for the fact the inverse of the Mills ratio is a generated regressor. In our original working paper Giné et al. (2010), this correction changed very little the standard errors as it only affected their tenth decimal. See also Benito (2006); Miles (1997) for similar arguments.
} 
interacted with the number of family members. The number of consecutive days worked and the interactions of days of the week with number of family members can clearly affect the participation decision by changing the marginal utility of leisure, but are unlikely to directly affect the expected amount of catches.

The first regressor shown in Panel A of Table 5 corresponds to the cumulative value of catches within the week. The results suggest that it is a positive and highly statistically significant predictor of the value of catches in any given day. This is not surprising given that catches are serially correlated.

The next set of estimates corresponds to the exogenous predictors of earnings. These variables will be used to instrument daily earnings in the structural participation probit estimation. As we can see, the INR-EUR exchange rate has a positive impact on the value of catches. The price of kerosene and the price of calamari are instead weak predictors of the value of catches. Nevertheless, they contribute to the joint significance and for this reason we keep them in our specifications. Finally, the lunar calendar dummies are significant predictors of earnings, with Full Moon (omitted category) being associated with lower earnings. These estimates have lower statistical significance in Column 3. This is confirmed by the F-statistic of joint significance of the instrumental variables reported in Panel B. The test statistic for columns 1 and 2 is statistically significant and higher than ten, which is the minimum recommended to obtain reliable estimates (Stock et al., 2002). However, that is not the case in Column 3, where we cannot reject the null hypothesis of weak instruments. The smaller sample using in Column 3 seems to reduce the variation in the dependent variable. For this reason, our preferred estimates are those reported in Column 2.

Panel B of Table 5 also shows the p-values of the test of joint significance of a number of additional regressors. As we can see, weather variables, dummies of the days of the week, month-year interactions, holidays and boat owner dummies are jointly significant predictors of earnings. ${ }^{31}$

\subsection{Participation Equation and Elasticities}

Table 6 presents the estimates of the structural participation probit of Equation 1. Predicted log-earnings are obtained by computing the fitted values of the corresponding column specification of Table 5. The instrumental variables used for the identification of predicted earnings are the INR-EUR exchange rate, the price of kerosene, the price of calamari, and the lunar calendar. In order to account for the presence of the predicted regressor "Predicted $\log$ (earnings)" we report the bootstrap standard errors (in parenthesis).

\footnotetext{
${ }^{31}$ See Appendix Table 2 for a complete set of estimates of all the regressors included.
} 
Panel A reports the main coefficients of interest. First, we observe that predicted earnings have positive and significant coefficients in all specifications: labor participation is more likely in days when higher earnings are expected. This result is consistent with Prediction 1 of the neoclassical model.

In order to asses the magnitude of these effects, Panel B reports two different participationwage elasticities. First, we report the average of the individual elasticities and, second, we report the elasticity when evaluated at the mean characteristics of boat owners. The values of the average individual elasticities range between 0.83 and 1.7, with 0.86 in our preferred sample (shown in Column 2). The elasticities at mean characteristics range between 0.79 and 1.3, with 0.79 in our preferred sample. As we can see these participation-wage elasticities are large in magnitude and, hence, suggest that boat owners intertemporally substitute leisure across days, and are considerably more willing to work when the expected wages are higher. These elasticities are slightly higher than the ones of stadium vendors, estimated by Oettinger (1999), which range between 0.55 and 0.75 . The elasticities of in our preferred sample are slightly lower than those of Swiss bike - estimated in Fehr and Goette (2007) ranging from 1.12 to 1.25 - and also those of lobster fishermen in Florida - estimated in Stafford (2015) ranging from 1.05 to 1.26. Stafford (2015) also estimates wage elasticities of daily hours ranging from 0.062 to 0.066 , which, consistent with the literature, suggests that Florida fishermen are more willing to adjust labor supply at the extensive margin in response to temporary variations in earnings. ${ }^{32}$

The last two regressors reported in Panel A are also consistent with Prediction 2 of our conceptual framework: individuals are less likely to work the more they have been working recently. Similar to the reduced-form participation probit, this result is only observed once we restrict the sample to weeks when the boat owner worked at least 3 days. The pattern of the coefficients is consistent with boat owners exhibiting substantial fatigue: the likelihood of not working is four time higher if the boat owner has been working for two or more consecutive day than if he has worked for only one consecutive day.

While, our conceptual framework predicts that cumulative catches during the previous days of the week should be unrelated to participation (Prediction 3), the results of Table 6 suggest that cumulative catches decrease the likelihood of labor participation. This result is consistent with the presence of reference-dependent preferences with a weekly target: higher cumulative catches within a week will increase the likelihood that the target is reached, consequently reducing the marginal utility of additional wage earnings and the likelihood of

\footnotetext{
${ }^{32}$ We note that the elasticities we estimate are calculated with respect to gross earnings. We cannot directly calculate net earnings elasticities since we do not have information on daily expenses on kerosene, laborers and other repairs. We have argued, however, that gross earnings are proportional to net earnings, and as a result, elasticities for net earnings should be similar to those presented here.
} 
labor participation. While this effect is statistically significant and robust across specifications, the magnitude of the effect is small. The elasticity at mean characteristics is -0.017 for our preferred sample. This represents 2 percent of the participation elasticity with respect to expected earnings. Therefore, while the data reject the neoclassical model, the role of reference-dependence is limited, suggesting that the neoclassical model may still be a good approximation.

We note that the magnitude of the elasticity with respect to recent earnings is twice as large in Column 2 compared to Column 1. This indicates that the evidence of referencedependent preferences only emerges when we exclude from the sample periods of extended absences. Hence, it suggests that identifying a sample when workers take labor participation decisions under normal circumstances is important to identify the patterns of their behavior. $^{33}$

\section{Robustness Checks}

In this section, we discuss the validity of our instrumental variables: the price of kerosene, the price of calamari, the INR-EUR exchange rate and the lunar calendar. These variables are valid instruments if they are correlated with daily wage earning and only affect the participation decision through its effect on expected value of catches.

If, for example, boat owners used kerosene for purposes other than fishing, such as cooking or lighting at home, then the price of kerosene may also affect the marginal utility of leisure. To address this concern, we incorporate the price of kerosene as a regressor to the structural probit equation, thus omitting it in the predicted wage regression as instrument. The results are reported in Table 7 . Column 1 shows our baseline preferred specification to facilitate the comparison. It corresponds to the specification shown in Column 2 of Table 6. In Column 2 of Table 7 we incorporate the price of kerosene to the structural participation equation. As we can see, the results are similar to the baseline specification and the F-statistic of the excluded instruments remain statistically significant.

By a similar argument, the price of calamari and the exchange rate INR-EUR might also affect the marginal utility of leisure if the prices of goods consumed by boat owners are also affected by international price fluctuations. We think this is unlikely because boat owners are relatively poor and they typically do not consume commodities traded in international markets. Nevertheless, in Column 3 of Table 7 we assess the robustness of our results to

\footnotetext{
${ }^{33}$ Consistent with this argument, the elasticity with respect to cumulative earnings is even larger when we restrict the sample to 4 or more consecutive days worked in Column 3. However, the weakness of the instrumental variables in this specification give us less confidence on the accuracy of its estimates.
} 
including these prices in the structural participation probit. Our results are robust to this specification.

Finally, we explore the validity of the lunar calendar as an instrumental variable. As previously discussed, there is an extended literature that links lunar phases with fish availability. However, it is also possible that the lunar calendar affects the marginal dis-utility from working, thus violating the exclusion restriction. One reason is night brightness: boat owners might prefer to fish during nights with full moon because getting oriented and conducting all fishing-related activities might be easier when there is more light. The fact that we observe lower likelihood of participation in full moon nights mitigates this concern. ${ }^{34}$ An additional link between the dis-utility to work and the lunar phase might be driven by tide variation. Every day, there are two high tides and two low tides. When there is full moon, high tides are very high and low tides are very low while this difference decreases during quarter moons. Therefore, sea conditions might also affect the dis-utility of going fishing if boat owners prefer not to sail under cycles with a higher sea tide variance. In order to test for this possibility, Column 4 of Table 7 explicitly incorporates dummies for the different lunar phases as regressors of the structural probit. As we can see, the results are unaffected.

\section{Discussion and Conclusions}

Most of the previous literature on labor supply has studied the intensive margin of participation decisions - how many hours to work - rather than the extensive margin - whether to work on a given day. However, the studies that are able to measure inter-temporal work elasticities in both margins, find that they are much larger in the extensive margin.

In this paper we use a dataset on daily labor force participation of Indian boat owners that we observe for 7 years. We develop an empirical strategy that allows us to estimate extensive margin elasticities. We find that a 10 percent increase in expected wages increases the likelihood of participation by 8 percent. The magnitude of these elasticities are similar to those found in the previous literature.

The richness of our data allows us to go beyond the specifications in previous studies and test for the preference of across-days spillovers in the opportunity cost of working. We flexibly control by fatigue and find evidence that boat owners are substantially less likely to fish if they have been working during the previous consecutive days. We also find that, conditional on recent participation, higher cumulative earnings within previous days of the week, decreases the likelihood of participation. This last results is at odds with the neoclassical model with time-separable utility and is consistent with models of reference-dependent preferences with

\footnotetext{
${ }^{34}$ See the reduced-form probit estimates in Table 4 where full moon is the omitted category.
} 
a weekly target. Furthermore, our results indicate that to correctly identify across-days spillovers, the sample needs to be restricted to weeks when workers were able to take their participation decisions in normal circumstances: the effects are more precisely estimated when periods of extended absences are eliminated from the sample.

While our results statistically reject the neoclassical model due to across-days preference spillovers, it is nevertheless a good approximation. The magnitude of participation elasticity with respect to recent earnings is 2 percent of the magnitude of the elasticity of expected earnings. Furthermore, in a specification where we entirely ignore across-days spilloversi.e., we omit consecutive days worked and cumulative earnings - we obtain inter-temporal elasticities that are very similar in magnitude to those in the model that includes across-days spillovers. $^{35}$

\footnotetext{
${ }^{35}$ In particular, if we omit consecutive days worked and cumulative earnings from both the earnings and structural probit equations, the resulting estimated earnings elasticity is 0.69 , while it is 0.79 in the specification that includes these variables. See the results in Appendix Table 4 for details.
} 


\section{References}

Abeler, J., A. Falk, L. Goette, And D. Huffman (2011): "Reference Points and Effort Provision," The American Economic Review, 101, pp. 470-492.

Barlow, R. B., M. K. Powers, H. Howard, And L. Kass (1986): "Migration of Limulus for Mating: Relation to Lunar Phase, Tide Height, and Sunlight," The Biological Bulletin, 171, 310-329.

Benito, A. (2006): "Does job insecurity affect household consumption?" Oxford Economic Papers, 58, 157-81.

Blundell, R. And T. MaCurdy (1999): "Labor Supply: a Review of Alternative Approaches," in Handbook of Labour Economics, ed. by O. Ashenfelter and D. Card, Elsevier, vol. 3, chap. 27, 1559-1695, 1 ed.

Camerer, C., L. Babcock, G. Loewenstein, and R. Thaler (1997): "Labor Supply of New York City Cabdrivers: One Day at a Time," Quarterly Journal of Economics, 112, $407-411$.

Chamberlain, G. (1980): "Analysis of Covariance with Qualitative Data," The Review of Economic Studies, 47, 225-238.

Chou, Y. (2002): "Testing Alternative Models of Labour Supply: Evidence from Taxi Drivers in Singapore," Singapore Economic Review, 47, 17-47.

Crawford, V. P. And J. Meng (2011): "New York City Cab Drivers' Labor Supply Revisited: Reference-Dependent Preferences with Rational-Expectations Targets for Hours and Income," American Economic Review, 101, 1912-1932.

Dupas, P., J. Robinson, And S. SaAvedra (2015): "The Daily Grind: Cash Needs, Labor Supply and Self-Control," Working paper, Stanford University.

Entright, J. (1975): "Orientation in Time: Endogenous Clocks, Physiological Mechanisms," in Marine Ecology, Wiley \& Sons, vol. 2, chap. 9.

FArber, H. S. (2005): "Is Tomorrow Another Day? The Labor Supply of New York City Cabdrivers," Journal of Political Economy, 113, 46-82.

(2008): "Reference-Dependent Preferences and Labor Supply: The Case of New York City Taxi Drivers," American Economic Review, 98, 1069-1082. 
Fehr, E. And L. Goette (2007): "Do Workers Work More if Wages Are High? Evidence from a Randomized Field Experiment," American Economic Review, 97, 298-317.

Giné, X., M. Martinez-Bravo, And M. Vidal-Fernández (2010): "Intertemporal Substitution or Reference-Dependent Preferences? Evidence from Daily Labor Supply of South Indian Boatowners," Working paper, World Bank.

GoldberG, J. (2016): "Kwacha Gonna Do? Experimental Evidence about Labor Supply in Rural Malawi," American Economic journal: Applied Economics, 8, 129-149.

Hastings, M. H. (1981): "Semi-Lunar Variations of Endogenous Circa-Tidal Rhythms of Activity and Respiration In the lsopod Eurydice pulchra," Marine Ecology - Progress Series, 4, 85-90.

Heckman, J. J. (1976): "The Common Structure of Statistical Models of Truncation, Sample Selection and Limited Dependent Variables and a Simple Estimator for Such Models," in Annals of Economic and Social Measurement, Volume 5, number 4, National Bureau of Economic Research, Inc, 475-492.

- (1993): "What Has Been Learned About Labor Supply in the Past Twenty Years?" American Economic Review, 83, 116-121.

Kahneman, D. And A. Tversky, eds. (2000): Choices, Values, and Frames, Cambridge University Press.

Köszegi, B. And M. Rabin (2006): "A Model of Reference-Dependent Preference," Quarterly Journal of Economics, 121, 1133-1165.

Luecke, C. And W. A. Wurtsbaugh (1993): "Effects of Moonlight and Daylight on Hydroacoustic Estimates of Pelagic Fish Abundance," Transactions of the American Fisheries Society, 122, 112-120.

Miles, D. (1997): "A household level study of the determinants of incomes and consumption," Economic Journal, 107, 1-25.

Oettinger, G. S. (1999): "An Empirical Analysis of the Daily Labor Supply of Stadium Vendors," American Economic Review, 107, 360-392.

Robertson, D. R., C. W. Petersen, and J. D. Brawn (1990): "Lunar Reproductive Cycles of Benthic-Brooding Reef Fishes: Reflections of Larval Biology or Adult Biology?" Ecological Monographs, 60, 311-329. 
Rossi, M. And S. Trucchi (2016): "Liquidity constraints and labor supply," European Economic Review, 87, 176-193.

Smith, M. (2002): "Two Econometric Approaches for Predicting the Spatial Behavior of Renewable Resource Harvesters," Land Economics, 78, 522-538.

Smith, M. And J. Wilen (2005): "Heterogeneous and Correlated Risk Preferences and Behavior of Commercial Fishermen: The Perfect Storm Dilemma," Journal of Risk and Uncertainty, 31, 53-71.

Stafford, T. (2015): "What Do Fishermen Tell Us That Taxi Drivers Don't? An Empirical Investigation of Labor Supply," Journal of Labor Economics, 33, 683-710.

Stock, J. H., J. H. Wright, And M. Yogo (2002): "A Survey of Weak Instruments and Weak Identication in Generalized Method of Moments," Journal of Business and Economic Statistics, 20, 518-529.

Tesch, F.-W. (1989): "Changes in Swimming Depth and Direction of Silver Eels (Anguilla anguilla L.) from the Continental Shelf to the Deep Sea," Aquatic Living Resources, 2, $9-20$.

Watson, R. and D. Pauly (2001): "Systematic Distortions in World Fisheries Catch, Trends," Nature, 414.

Zucker, N. (1978): "Monthly Reproductive Cycles in Three Sympatric Hood building Tropical Fiddler Crabs (Genus Uca)," The Biological Bulletin, 155, 410-424. 
Figure 1. Participation during Days of Week

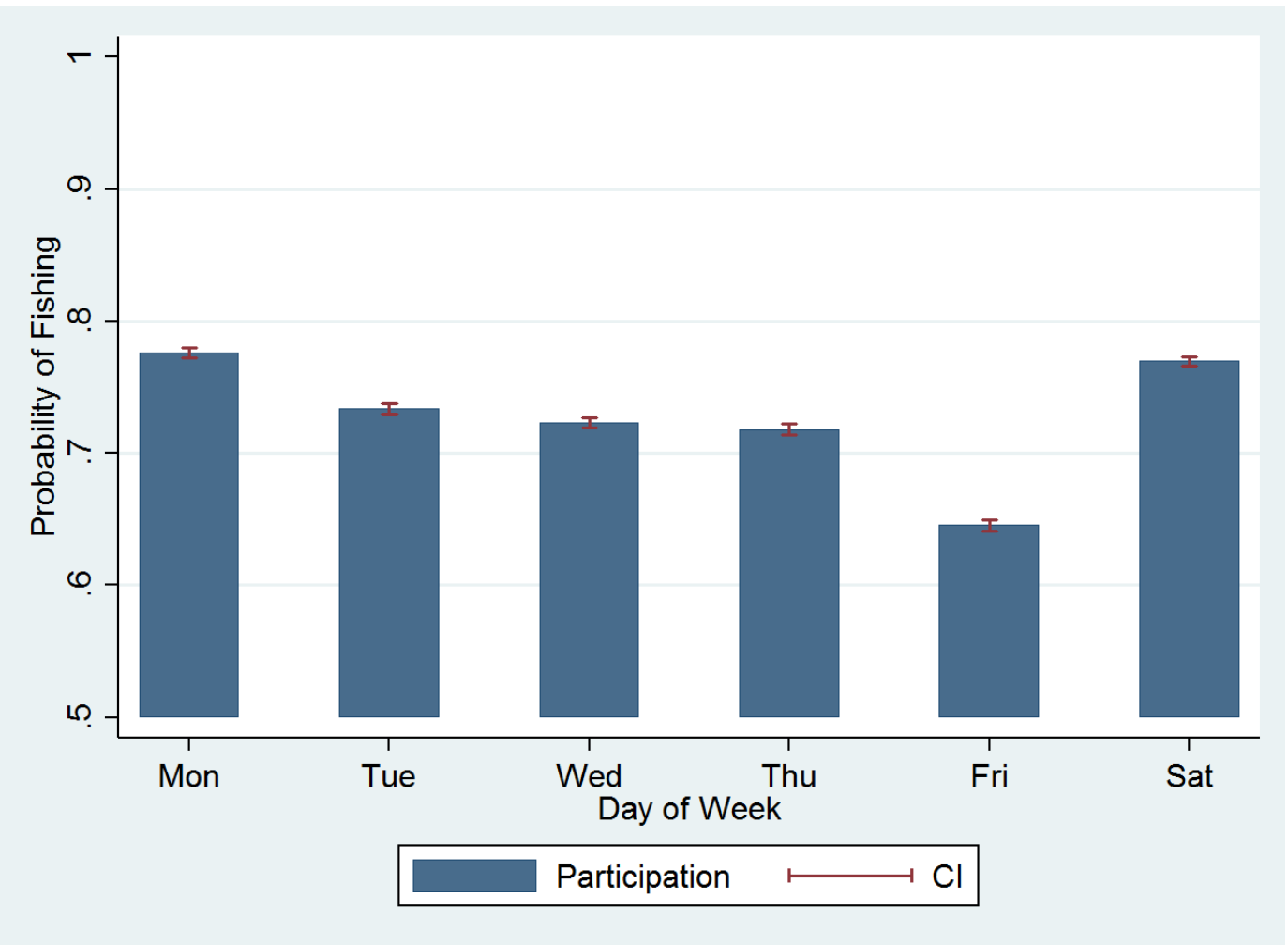


Figure 2. Villages in Tamil Nadu
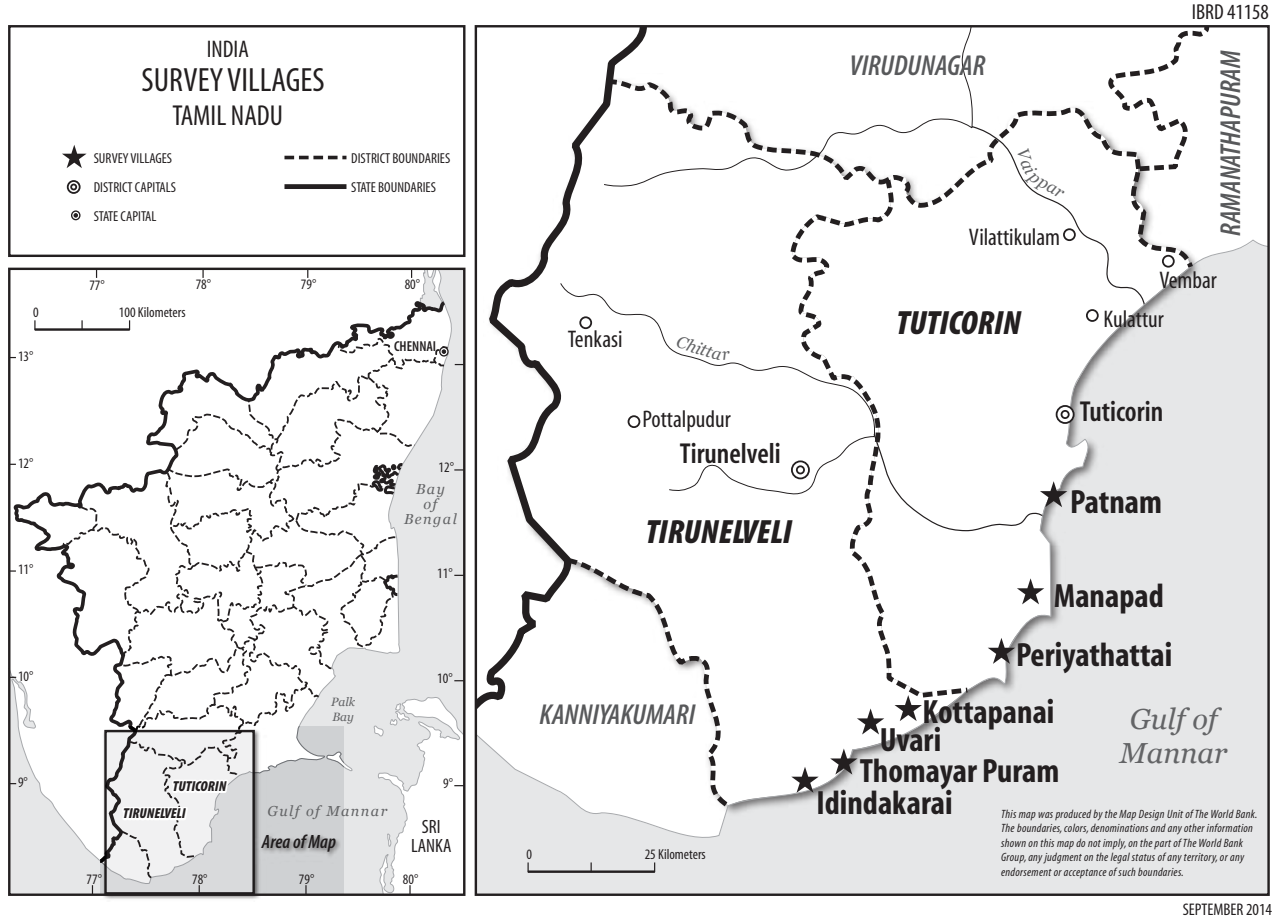
Table 1. Summary Statistics

\begin{tabular}{lccc}
\hline \hline & N. Obs. & Mean & Std. Dev. \\
\hline Age & 243 & 42.00 & 9.16 \\
Total family members & 243 & 4.79 & 1.41 \\
Number of income earners & 243 & 2.05 & 0.99 \\
Number of children & 243 & 1.42 & 1.28 \\
Years of education & 242 & 5.59 & 2.13 \\
Savings in INR & 243 & 2,647 & 3,144 \\
Daily participation & 243 & 0.73 & 0.10 \\
Daily value of catches (INR) & 243 & 1,076 & 332 \\
Average daily costs in kerosene and laborers (INR) & 243 & 764 & 217 \\
\hline
\end{tabular}

Notes: Data collected in 2007. All monetary values are expressed in 2007 INR.

Table 2. Determinants of boat owners' Earnings

\begin{tabular}{lcc}
\hline \hline & Mean & Std. Dev. \\
\cline { 2 - 3 } Price of calamari & 3.27 & 0.44 \\
Real exchange rate INR-EUR & 4.05 & 0.09 \\
Price of kerosene in INR per gallon & 62.77 & 21.66 \\
& & \\
Wind direction Northeast & 0.24 & 0.43 \\
Maximum temperature & 31.16 & 1.66 \\
Minimum temperature & 24.79 & 1.35 \\
Average wind speed (Km. per hour) & 14.67 & 5.89 \\
Total Rainfall in millimeters & 2.04 & 7.94 \\
Rainfall duration & 0.44 & 1.63 \\
Rainfall dummy & 0.18 & 0.39 \\
Drizzle dummy & 0.16 & 0.36 \\
& & \\
Number of observed periods & 1,994 & \\
\hline Notes: Datacollected for 2001-2007. &
\end{tabular}

Notes: Data collected for 2001-2007. 
Table 3. Identification: Summary of Variables Included in Each Regression

\begin{tabular}{lccc}
\hline \hline & $\begin{array}{c}\text { Reduced-Form } \\
\text { Participation } \\
\text { (Table 4) }\end{array}$ & $\begin{array}{c}\text { Earnings } \\
\text { Equation (Table }\end{array}$ & $\begin{array}{c}\text { Structural } \\
\text { Participation } \\
\text { Equation } \\
\text { (Table 6) }\end{array}$ \\
\hline Predicted log(earnings) & $\checkmark$ & $\checkmark$ & $\checkmark$ \\
Log (Cumulative value of catches within week) & $\checkmark$ & $\checkmark$ & $\checkmark$ \\
Day of the week dummies & $\checkmark$ & $\checkmark$ & $\checkmark$ \\
Holiday dummy & $\checkmark$ & $\checkmark$ & $\checkmark$ \\
Month-year dummies & $\checkmark$ & $\checkmark$ & $\checkmark$ \\
Measures of weather conditions & $\checkmark$ & $\checkmark$ & $\checkmark$ \\
Boat owner dummies & $\checkmark$ & $\checkmark$ & $\checkmark$ \\
Consecutive days worked & $\checkmark$ & $\checkmark$ & \\
Day of the week-family members interactions & $\checkmark$ & & \\
Log (Real exchange rate INR-EUR) & $\checkmark$ & & \\
Log (Price of kerosene) & & $\checkmark$ & \\
Dummies for Lunar Phase calendar & $\checkmark$ & & $\checkmark$ \\
\hline
\end{tabular}


Table 4. Reduced Form Participation Estimates. Probit Model

\begin{tabular}{|c|c|c|c|}
\hline & \multicolumn{3}{|c|}{ Dependent variable: Participation } \\
\hline & (1) & (2) & (3) \\
\hline & Base Sample & $\begin{array}{l}\text { More than } 3 \text { days } \\
\text { worked per week }\end{array}$ & $\begin{array}{l}\text { More than } 4 \text { days } \\
\text { worked per week }\end{array}$ \\
\hline \multirow[t]{2}{*}{ Mean Dep. Var. } & 0.73 & 0.78 & 0.83 \\
\hline & \multicolumn{3}{|c|}{ A. Coefficient Estimates and Standard Errors } \\
\hline Log (Cumulative value of catches within week) & $\begin{array}{c}0.019 * * * \\
(0.001)\end{array}$ & $\begin{array}{l}-0.001 \\
(0.002)\end{array}$ & $\begin{array}{c}-0.014 * * * \\
(0.002)\end{array}$ \\
\hline Log (Real exchange rate INR-EUR) & $\begin{array}{c}1.839 * * * \\
(0.259)\end{array}$ & $\begin{array}{c}1.516^{* * * *} \\
(0.278)\end{array}$ & $\begin{array}{c}1.676 * * * \\
(0.303)\end{array}$ \\
\hline Log (Price of kerosene) & $\begin{array}{c}-0.177 * * \\
(0.074)\end{array}$ & $\begin{array}{c}-0.195 * * \\
(0.080)\end{array}$ & $\begin{array}{l}-0.145 \\
(0.091)\end{array}$ \\
\hline Log (Price of calamari) & $\begin{array}{c}0.079 \\
(0.062)\end{array}$ & $\begin{array}{l}0.115^{*} \\
(0.063)\end{array}$ & $\begin{array}{l}0.137 * \\
(0.071)\end{array}$ \\
\hline First Quarter Moon & $\begin{array}{c}0.009 \\
(0.007)\end{array}$ & $\begin{array}{l}0.031 * * * \\
(0.008)\end{array}$ & $\begin{array}{c}0.033 * * * \\
(0.009)\end{array}$ \\
\hline New Moon & $\begin{array}{l}-0.000 \\
(0.007)\end{array}$ & $\begin{array}{c}0.013 \\
(0.008)\end{array}$ & $\begin{array}{c}0.026 * * * \\
(0.009)\end{array}$ \\
\hline Last Quarter Moon & $\begin{array}{c}0.033 * * * \\
(0.007)\end{array}$ & $\begin{array}{l}0.033 * * * \\
(0.008)\end{array}$ & $\begin{array}{l}0.022 * * \\
(0.009)\end{array}$ \\
\hline One consecutive day worked & $\begin{array}{c}0.058 * * * \\
(0.011)\end{array}$ & $\begin{array}{c}-0.043^{* * * *} \\
(0.013)\end{array}$ & $\begin{array}{c}-0.159 * * * \\
(0.013)\end{array}$ \\
\hline \multirow[t]{2}{*}{ Two or more consecutive days worked } & $\begin{array}{c}0.055^{* * * *} \\
(0.010)\end{array}$ & $\begin{array}{c}-0.194 * * * \\
(0.011)\end{array}$ & $\begin{array}{c}-0.381 * * * \\
(0.011)\end{array}$ \\
\hline & \multicolumn{3}{|c|}{ B. Chi ${ }^{2}$ Statistic p-Values of Joint Significance } \\
\hline Weather variables & $<0.001$ & $<0.001$ & $<0.001$ \\
\hline Day of the week dummies & $<0.001$ & $<0.001$ & $<0.001$ \\
\hline Month-year dummies & $<0.001$ & $<0.001$ & $<0.001$ \\
\hline Holiday dummy & $<0.001$ & $<0.001$ & $<0.001$ \\
\hline Boat owner dumies & $<0.001$ & $<0.001$ & $<0.001$ \\
\hline Day of the week-family members interactions & $<0.001$ & $<0.001$ & $<0.001$ \\
\hline Observations & 265,565 & 239,248 & 199,355 \\
\hline
\end{tabular}


Table 5. Estimation of Log Earnings Equation

\begin{tabular}{|c|c|c|c|}
\hline & \multicolumn{3}{|c|}{ Dependent variable: Log Value of Catches } \\
\hline & $(1)$ & (2) & (3) \\
\hline & Base Sample & $\begin{array}{l}\text { More than } 3 \text { days } \\
\text { worked per week }\end{array}$ & $\begin{array}{l}\text { More than } 4 \text { days } \\
\text { worked per week }\end{array}$ \\
\hline \multirow[t]{2}{*}{ Mean Dep. Var. (not logged) } & 679 & 729 & 786 \\
\hline & \multicolumn{3}{|c|}{ A. Coefficient Estimates and Standard Errors } \\
\hline Log (Cumulative value of catches within week) & $\begin{array}{l}0.017 * * * \\
(0.001)\end{array}$ & $\begin{array}{c}0.020 * * * \\
(0.001)\end{array}$ & $\begin{array}{c}0.035 * * * \\
(0.001)\end{array}$ \\
\hline Log (Real exchange rate INR-EUR) & $\begin{array}{c}0.710 * * * \\
(0.173)\end{array}$ & $\begin{array}{c}0.655^{* * * *} \\
(0.176)\end{array}$ & $\begin{array}{l}0.359 * \\
(0.196)\end{array}$ \\
\hline Log (Price of kerosene) & $\begin{array}{l}-0.034 \\
(0.047)\end{array}$ & $\begin{array}{l}-0.043 \\
(0.049)\end{array}$ & $\begin{array}{l}-0.010 \\
(0.055)\end{array}$ \\
\hline Log (Price of calamari) & $\begin{array}{c}0.009 \\
(0.040)\end{array}$ & $\begin{array}{c}0.003 \\
(0.041)\end{array}$ & $\begin{array}{c}0.016 \\
(0.047)\end{array}$ \\
\hline First Quarter Moon & $\begin{array}{c}0.013 * * * \\
(0.004)\end{array}$ & $\begin{array}{l}0.010 * * \\
(0.004)\end{array}$ & $\begin{array}{c}0.002 \\
(0.005)\end{array}$ \\
\hline New Moon & $\begin{array}{l}0.009 * * \\
(0.004)\end{array}$ & $\begin{array}{l}0.008 * \\
(0.004)\end{array}$ & $\begin{array}{c}0.000 \\
(0.005)\end{array}$ \\
\hline \multirow[t]{2}{*}{ Last Quarter Moon } & $\begin{array}{c}0.019 * * * \\
(0.004)\end{array}$ & $\begin{array}{c}0.016^{* * *} \\
(0.004)\end{array}$ & $\begin{array}{c}0.005 \\
(0.005)\end{array}$ \\
\hline & \multicolumn{3}{|c|}{ B. Chi ${ }^{2}$ Statistic p-Values of Joint Significance } \\
\hline Weather variables & $<0.001$ & $<0.001$ & $<0.001$ \\
\hline Day of the week dummies & $<0.001$ & $<0.001$ & $<0.001$ \\
\hline Month-year dummies & $<0.001$ & $<0.001$ & $<0.001$ \\
\hline Holiday dummy & & $<0.001$ & $<0.001$ \\
\hline Boat owner dumies & $<0.001$ & $<0.001$ & $<0.001$ \\
\hline $\begin{array}{l}\text { F-Statistic of joint significance of instrumental variables } \\
\text { p-value }\end{array}$ & $\begin{array}{c}37.41 \\
<0.001\end{array}$ & $\begin{array}{c}28.47 \\
<0.001\end{array}$ & $\begin{array}{l}4.690 \\
0.584\end{array}$ \\
\hline Rho & $\begin{array}{c}0.042 \\
(0.008)\end{array}$ & $\begin{array}{c}0.005 \\
(0.016)\end{array}$ & $\begin{array}{l}-0.805 \\
(0.006)\end{array}$ \\
\hline Observations & 265,565 & 239,248 & 199,355 \\
\hline
\end{tabular}


Table 6. Structural Participation Equation. Probit Model

\begin{tabular}{|c|c|c|c|}
\hline & \multicolumn{3}{|c|}{ Dependent variable: Participation } \\
\hline & (1) & (2) & (3) \\
\hline & Base Sample & $\begin{array}{l}\text { More than } 3 \text { days } \\
\text { worked per week }\end{array}$ & $\begin{array}{l}\text { More than } 4 \text { days } \\
\text { worked per week }\end{array}$ \\
\hline \multirow[t]{2}{*}{ Mean Dep. Var. } & 0.73 & 0.78 & 0.83 \\
\hline & \multicolumn{3}{|c|}{ A. Coefficient Estimates and Standard Errors } \\
\hline Predicted log(earnings) & $\begin{array}{l}2.072 * * * \\
(0.248)\end{array}$ & $\begin{array}{l}2.262 * * * \\
(0.366)\end{array}$ & $\begin{array}{c}4.798 * * * \\
(0.853)\end{array}$ \\
\hline Log (Cumulative value of catches within week) & $\begin{array}{c}-0.017 * * * \\
(0.005)\end{array}$ & $\begin{array}{l}-0.047 * * * \\
(0.008)\end{array}$ & $\begin{array}{c}-0.186 * * * \\
(0.030)\end{array}$ \\
\hline One consecutive day worked & $\begin{array}{l}0.054 * * * \\
(0.009)\end{array}$ & $\begin{array}{c}-0.043 * * * \\
(0.011)\end{array}$ & $\begin{array}{c}-0.073 * * * \\
(0.018)\end{array}$ \\
\hline \multirow[t]{2}{*}{ Two or more consecutive days worked } & $\begin{array}{c}0.054 * * * \\
(0.007)\end{array}$ & $\begin{array}{c}-0.194 * * * \\
(0.009)\end{array}$ & $\begin{array}{c}-0.430 * * * \\
(0.015)\end{array}$ \\
\hline & \multicolumn{3}{|c|}{ B. Chi ${ }^{2}$ Statistic p-Values of Joint Significance } \\
\hline Weather variables & $<0.001$ & $<0.001$ & $<0.001$ \\
\hline Day of the week dummies & $<0.001$ & $<0.001$ & $<0.001$ \\
\hline Month-year dummies & $<0.001$ & $<0.001$ & $<0.001$ \\
\hline Holiday dummy & $<0.001$ & $<0.001$ & $<0.001$ \\
\hline Boat owner dumies & $<0.001$ & $<0.001$ & $<0.001$ \\
\hline Consecutive days worked & $<0.001$ & $<0.001$ & $<0.001$ \\
\hline \multirow[t]{2}{*}{ Day of the week-family members interactions } & $<0.001$ & $<0.001$ & $<0.001$ \\
\hline & \multicolumn{3}{|c|}{ C. Elasticities } \\
\hline $\begin{array}{l}\text { Predicted } \log (\text { earnings }) \\
\text { [Mean of Individual Elasticities] }\end{array}$ & $\begin{array}{c}0.832 \\
(0.139)\end{array}$ & $\begin{array}{c}0.861 \\
(0.128)\end{array}$ & $\begin{array}{c}1.708 \\
(0.227)\end{array}$ \\
\hline $\begin{array}{l}\text { Predicted log(earnings) } \\
\text { [Elasticity at Mean Characteristics] }\end{array}$ & $\begin{array}{c}0.872 \\
(0.104)\end{array}$ & $\begin{array}{c}0.795 \\
(0.129)\end{array}$ & $\begin{array}{c}1.286 \\
(0.229)\end{array}$ \\
\hline $\begin{array}{l}\text { Log (Cumulative value of catches within week) } \\
\text { [Elasticity at Mean Characteristics] }\end{array}$ & $\begin{array}{l}-0.007 \\
(0.002)\end{array}$ & $\begin{array}{l}-0.017 \\
(0.003)\end{array}$ & $\begin{array}{l}-0.050 \\
(0.008)\end{array}$ \\
\hline Observations & 265,565 & 239,248 & 199,355 \\
\hline
\end{tabular}

Notes: Bootstrap standard errors in parentheses. The unit of observation is a boat-owner-day. The dependent variable is a dummy that takes value 1 if the boat owner went fishing on a particular day. All regressions include boat owner dummies and a full set of month-year dummies. See Appendix Table 3 for the point estimates of all regressors included. 
Table 7. Robustness Checks. Structural Participation Equation

\begin{tabular}{|c|c|c|c|c|}
\hline & \multicolumn{4}{|c|}{ Dependent variable: Participation } \\
\hline & $(1)$ & $(2)$ & (3) & $(4)$ \\
\hline Predicted $\log$ (earnings) & $\begin{array}{c}2.262 * * * \\
(0.366)\end{array}$ & $\begin{array}{c}2.345^{* * *} \\
(0.385)\end{array}$ & $\begin{array}{c}2.247 * * * \\
(0.364)\end{array}$ & $\begin{array}{c}2.333 * * * \\
(0.526)\end{array}$ \\
\hline Log (Cumulative value of catches within week) & $\begin{array}{c}-0.047 * * * \\
(0.008)\end{array}$ & $\begin{array}{c}-0.049 * * * \\
(0.008)\end{array}$ & $\begin{array}{c}-0.047 * * * \\
(0.008)\end{array}$ & $\begin{array}{c}-0.048 * * * \\
(0.011)\end{array}$ \\
\hline One consecutive day worked & $\begin{array}{c}-0.043 * * * \\
(0.011)\end{array}$ & $\begin{array}{c}-0.043 * * * \\
(0.011)\end{array}$ & $\begin{array}{c}-0.043 * * * \\
(0.011)\end{array}$ & $\begin{array}{c}-0.043 * * * \\
(0.011)\end{array}$ \\
\hline Two or more consecutive days worked & $\begin{array}{c}-0.194 * * * \\
(0.009)\end{array}$ & $\begin{array}{c}-0.194 * * * \\
(0.009)\end{array}$ & $\begin{array}{c}-0.194 * * * \\
(0.009)\end{array}$ & $\begin{array}{c}-0.194 * * * \\
(0.009)\end{array}$ \\
\hline $\begin{array}{l}\text { F-Statistic of joint significance of instrumental variables } \\
\text { p-value }\end{array}$ & $\begin{array}{c}28.47 \\
<0.001\end{array}$ & $\begin{array}{c}28.47 \\
<0.001\end{array}$ & $\begin{array}{l}15.20 \\
0.004\end{array}$ & $\begin{array}{l}13.79 \\
0.003\end{array}$ \\
\hline $\begin{array}{l}\text { Instrumental Variables to identify predicted earnings: } \\
\text { Log (Price of kerosene) }\end{array}$ & $\checkmark$ & & $\checkmark$ & $\checkmark$ \\
\hline Log (Real exchange rate INR-EUR) & $\checkmark$ & $\checkmark$ & & $\checkmark$ \\
\hline Log (Price of calamari) & $\checkmark$ & $\sqrt{ }$ & & $\checkmark$ \\
\hline First Quarter Moon & $\checkmark$ & $\checkmark$ & $\checkmark$ & \\
\hline New Moon & $\checkmark$ & $\checkmark$ & $\checkmark$ & \\
\hline Last Quarter Moon & $\checkmark$ & $\checkmark$ & $\checkmark$ & \\
\hline Observations & 239,248 & 239,248 & 239,248 & 239,248 \\
\hline
\end{tabular}


[Appendix. For Online Publication Only] 
Appendix Table 1. Reduced Form Participation, Full Set of Estimates (Table 4)

\begin{tabular}{|c|c|c|c|}
\hline & \multicolumn{3}{|c|}{ 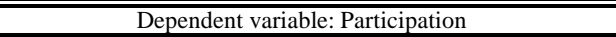 } \\
\hline & (1) & (2) & (3) \\
\hline & Base Sample & $\begin{array}{l}\text { More than } 3 \text { days } \\
\text { worked per week }\end{array}$ & $\begin{array}{l}\text { More than } 4 \text { days } \\
\text { worked per week }\end{array}$ \\
\hline Mean Dep. Var. & 0.73 & 0.78 & 0.83 \\
\hline Log (Cumulative value of catches within week) & $\begin{array}{l}0.019 * * * \\
(0.001)\end{array}$ & $\begin{array}{l}-0.001 \\
(0.002)\end{array}$ & $\begin{array}{c}-0.014 * * * \\
(0.002)\end{array}$ \\
\hline Log (Real exchange rate INR-EUR) & $\begin{array}{c}1.839 * * * \\
(0.259)\end{array}$ & $\begin{array}{c}1.516 * * * \\
(0.278)\end{array}$ & $\begin{array}{c}1.676 * * * \\
(0.303)\end{array}$ \\
\hline Log (Price of kerosene) & $\begin{array}{c}-0.177 * * \\
(0.074)\end{array}$ & $\begin{array}{c}-0.195 * * \\
(0.080)\end{array}$ & $\begin{array}{c}-0.145 \\
(0.091)\end{array}$ \\
\hline Log (Price of calamari) & $\begin{array}{c}0.079 \\
(0.062)\end{array}$ & $\begin{array}{l}0.115^{*} \\
(0.063)\end{array}$ & $\begin{array}{l}0.137 * \\
(0.071)\end{array}$ \\
\hline First Quarter Moon & $\begin{array}{c}0.009 \\
(0.007)\end{array}$ & $\begin{array}{c}0.031 * * * \\
(0.008)\end{array}$ & $\begin{array}{c}0.033 * * * \\
(0.009)\end{array}$ \\
\hline New Moon & $\begin{array}{l}-0.000 \\
(0.007)\end{array}$ & $\begin{array}{c}0.013 \\
(0.008)\end{array}$ & $\begin{array}{c}0.026 * * * \\
(0.009)\end{array}$ \\
\hline Last Quarter Moon & $\begin{array}{c}0.033 * * * \\
(0.007)\end{array}$ & $\begin{array}{c}0.033 * * * \\
(0.008)\end{array}$ & $\begin{array}{l}0.022 * * \\
(0.009)\end{array}$ \\
\hline Wind direction Northeast & $\begin{array}{c}-0.039 * * * \\
(0.009)\end{array}$ & $\begin{array}{c}-0.031 * * * \\
(0.010)\end{array}$ & $\begin{array}{c}-0.040 * * * \\
(0.011)\end{array}$ \\
\hline Maximum temperature & $\begin{array}{c}0.006^{* * *} \\
(0.002)\end{array}$ & $\begin{array}{c}0.006^{* *} * \\
(0.003)\end{array}$ & $\begin{array}{c}0.007 * * \\
(0.003)\end{array}$ \\
\hline Minimum temperature & $\begin{array}{c}0.007 \text { ** } \\
(0.004)\end{array}$ & $\begin{array}{l}-0.001 \\
(0.004)\end{array}$ & $\begin{array}{l}-0.007 * \\
(0.004)\end{array}$ \\
\hline Average wind speed (Km. per hour) & $\begin{array}{l}-0.001 \\
(0.001)\end{array}$ & $\begin{array}{c}0.000 \\
(0.001)\end{array}$ & $\begin{array}{c}-0.001 \\
(0.001)\end{array}$ \\
\hline Total Rainfall & $\begin{array}{l}-0.001^{*} \\
(0.000)\end{array}$ & $\begin{array}{l}-0.000 \\
(0.001)\end{array}$ & $\begin{array}{c}-0.001 * * \\
(0.001)\end{array}$ \\
\hline Rainfall duration & $\begin{array}{c}-0.009 * * * \\
(0.002)\end{array}$ & $\begin{array}{c}-0.016 * * * \\
(0.002)\end{array}$ & $\begin{array}{c}-0.009 * * * \\
(0.003)\end{array}$ \\
\hline Rain dummy & $\begin{array}{c}-0.049 * * * \\
(0.009)\end{array}$ & $\begin{array}{c}-0.039 * * * \\
(0.010)\end{array}$ & $\begin{array}{c}-0.034 * * * \\
(0.011)\end{array}$ \\
\hline Drizzle dummy & $\begin{array}{c}-0.040 * * * \\
(0.009)\end{array}$ & $\begin{array}{l}-0.002 \\
(0.010)\end{array}$ & $\begin{array}{c}0.008 \\
(0.011)\end{array}$ \\
\hline First Friday of the month & $\begin{array}{c}-0.744 * * * \\
(0.017)\end{array}$ & $\begin{array}{c}-0.822 * * * \\
(0.018)\end{array}$ & $\begin{array}{c}-0.850 * * * \\
(0.021)\end{array}$ \\
\hline Holiday dummy & $\begin{array}{c}-0.940 * * * \\
(0.021)\end{array}$ & $\begin{array}{c}-1.016^{* * * *} \\
(0.023)\end{array}$ & $\begin{array}{c}-0.989 * * * \\
(0.026)\end{array}$ \\
\hline Week with the first Friday of the month & $\begin{array}{c}0.054 * * * \\
(0.007)\end{array}$ & $\begin{array}{c}0.105 * * * \\
(0.008)\end{array}$ & $\begin{array}{c}0.145^{* * * *} \\
(0.009)\end{array}$ \\
\hline Monday & $\begin{array}{c}0.383 * * * \\
(0.034)\end{array}$ & $\begin{array}{l}-0.015 \\
(0.041)\end{array}$ & $\begin{array}{c}-0.394 * * * \\
(0.044)\end{array}$ \\
\hline Tuesday & $\begin{array}{c}0.001 \\
(0.033)\end{array}$ & $\begin{array}{c}-0.153 * * * \\
(0.037)\end{array}$ & $\begin{array}{c}-0.237 * * * \\
(0.040)\end{array}$ \\
\hline Wednesday & $\begin{array}{c}-0.118 * * * \\
(0.033)\end{array}$ & $\begin{array}{c}-0.167 * * * \\
(0.037)\end{array}$ & $\begin{array}{c}-0.103 * * * \\
(0.038)\end{array}$ \\
\hline Thursday & $\begin{array}{c}-0.132 * * * \\
(0.032)\end{array}$ & $\begin{array}{c}-0.142^{* * * *} \\
(0.036)\end{array}$ & $\begin{array}{c}-0.143 * * * \\
(0.037)\end{array}$ \\
\hline Friday & $\begin{array}{l}0.059^{*} \\
(0.031)\end{array}$ & $\begin{array}{l}0.059^{*} \\
(0.035)\end{array}$ & $\begin{array}{l}0.063^{*} \\
(0.036)\end{array}$ \\
\hline One consecutive day worked & $\begin{array}{c}0.058 * * * \\
(0.011)\end{array}$ & $\begin{array}{c}-0.043^{* * * *} \\
(0.013)\end{array}$ & $\begin{array}{c}-0.159 * * * \\
(0.013)\end{array}$ \\
\hline Two or more consecutive days worked & $\begin{array}{c}0.055^{* * * *} \\
(0.010)\end{array}$ & $\begin{array}{c}-0.194 * * * \\
(0.011)\end{array}$ & $\begin{array}{c}-0.381 * * * \\
(0.011)\end{array}$ \\
\hline Monday x Number of family members & $\begin{array}{c}-0.015^{* *} \\
(0.006)\end{array}$ & $\begin{array}{l}-0.013 * \\
(0.007)\end{array}$ & $\begin{array}{l}-0.002 \\
(0.007)\end{array}$ \\
\hline Tuesday x Number of family members & $\begin{array}{l}-0.010 * \\
(0.006)\end{array}$ & $\begin{array}{l}-0.008 \\
(0.007)\end{array}$ & $\begin{array}{l}-0.005 \\
(0.007)\end{array}$ \\
\hline Wednesday $\mathrm{x}$ Number of family members & $\begin{array}{l}-0.001 \\
(0.006)\end{array}$ & $\begin{array}{c}0.005 \\
(0.007)\end{array}$ & $\begin{array}{c}-0.009 \\
(0.007)\end{array}$ \\
\hline Thursday x Number of family members & $\begin{array}{l}-0.006 \\
(0.006)\end{array}$ & $\begin{array}{l}-0.003 \\
(0.007)\end{array}$ & $\begin{array}{l}-0.003 \\
(0.007)\end{array}$ \\
\hline Friday $\mathrm{x}$ Number of family members & $\begin{array}{c}-0.053 * * * \\
(0.006)\end{array}$ & $\begin{array}{c}-0.052 * * * \\
(0.006)\end{array}$ & $\begin{array}{c}-0.050 * * * \\
(0.007)\end{array}$ \\
\hline Observations & 265,565 & 239,248 & 199,355 \\
\hline
\end{tabular}




\section{Appendix Table 2. Estimation of Log Earnings Equation, Full Set of Estimates (Table 5)}

\begin{tabular}{|c|c|c|c|}
\hline & \multicolumn{3}{|c|}{ Dependent variable: Log Value of Catches } \\
\hline & (1) & (2) & (3) \\
\hline & Base Sample & $\begin{array}{l}\text { More than } 3 \text { days } \\
\text { worked per week }\end{array}$ & $\begin{array}{l}\text { More than } 4 \text { days } \\
\text { worked per week }\end{array}$ \\
\hline Mean Dep. Var. (not logged) & 679 & 729 & 786 \\
\hline Log (Cumulative value of catches within week) & $\begin{array}{c}0.017 * * * \\
(0.001)\end{array}$ & $\begin{array}{c}0.020^{* * * *} \\
(0.001)\end{array}$ & $\begin{array}{c}0.035^{* * *} \\
(0.001)\end{array}$ \\
\hline Log (Real exchange rate INR-EUR) & $\begin{array}{c}0.710^{* * * *} \\
(0.173)\end{array}$ & $\begin{array}{c}0.655^{* * *} \\
(0.176)\end{array}$ & $\begin{array}{l}0.359^{*} \\
(0.196)\end{array}$ \\
\hline Log (Price of kerosene) & $\begin{array}{l}-0.034 \\
(0.047)\end{array}$ & $\begin{array}{l}-0.043 \\
(0.049)\end{array}$ & $\begin{array}{l}-0.010 \\
(0.055)\end{array}$ \\
\hline Log (Price of calamari) & $\begin{array}{c}0.009 \\
(0.040)\end{array}$ & $\begin{array}{c}0.003 \\
(0.041)\end{array}$ & $\begin{array}{c}0.016 \\
(0.047)\end{array}$ \\
\hline First Quarter Moon & $\begin{array}{c}0.013 * * * \\
(0.004)\end{array}$ & $\begin{array}{l}0.010 * * \\
(0.004)\end{array}$ & $\begin{array}{c}0.002 \\
(0.005)\end{array}$ \\
\hline New Moon & $\begin{array}{l}0.009 * * \\
(0.004)\end{array}$ & $\begin{array}{l}0.008^{*} \\
(0.004)\end{array}$ & $\begin{array}{c}0.000 \\
(0.005)\end{array}$ \\
\hline Last Quarter Moon & $\begin{array}{c}0.019^{* * *} \\
(0.004)\end{array}$ & $\begin{array}{c}0.016^{* * *} \\
(0.004)\end{array}$ & $\begin{array}{c}0.005 \\
(0.005)\end{array}$ \\
\hline Wind direction Northeast & $\begin{array}{c}-0.014 * * * \\
(0.005)\end{array}$ & $\begin{array}{c}-0.011^{* *} \\
(0.005)\end{array}$ & $\begin{array}{l}-0.002 \\
(0.006)\end{array}$ \\
\hline Maximum temperature & $\begin{array}{c}0.001 \\
(0.001)\end{array}$ & $\begin{array}{l}-0.000 \\
(0.001)\end{array}$ & $\begin{array}{c}0.000 \\
(0.002)\end{array}$ \\
\hline Minimum temperature & $\begin{array}{c}-0.005^{* * * *} \\
(0.002)\end{array}$ & $\begin{array}{c}-0.007 * * * \\
(0.002)\end{array}$ & $\begin{array}{c}-0.006 * * * \\
(0.002)\end{array}$ \\
\hline Average wind speed (Km. per hour) & $\begin{array}{c}-0.001 * * * \\
(0.000)\end{array}$ & $\begin{array}{c}-0.001 * * * \\
(0.000)\end{array}$ & $\begin{array}{l}-0.001 * * \\
(0.000)\end{array}$ \\
\hline Total Rainfall & $\begin{array}{l}-0.000 \\
(0.000)\end{array}$ & $\begin{array}{l}-0.000 * \\
(0.000)\end{array}$ & $\begin{array}{l}-0.000 \\
(0.000)\end{array}$ \\
\hline Rainfall duration & $\begin{array}{l}-0.002 \\
(0.001)\end{array}$ & $\begin{array}{l}-0.002 * \\
(0.001)\end{array}$ & $\begin{array}{l}-0.001 \\
(0.001)\end{array}$ \\
\hline Rain dummy & $\begin{array}{l}0.012 * * \\
(0.005)\end{array}$ & $\begin{array}{c}0.014 * * * \\
(0.005)\end{array}$ & $\begin{array}{c}0.020 * * * \\
(0.006)\end{array}$ \\
\hline Drizzle dummy & $\begin{array}{l}-0.006 \\
(0.005)\end{array}$ & $\begin{array}{l}-0.007 \\
(0.005)\end{array}$ & $\begin{array}{l}-0.010^{*} \\
(0.006)\end{array}$ \\
\hline First Friday of the month & $\begin{array}{l}-0.001 \\
(0.011)\end{array}$ & $\begin{array}{c}0.006 \\
(0.012)\end{array}$ & $\begin{array}{c}0.265^{* * *} \\
(0.014)\end{array}$ \\
\hline Holiday dummy & $\begin{array}{l}-0.001 \\
(0.017)\end{array}$ & $\begin{array}{c}0.009 \\
(0.019)\end{array}$ & $\begin{array}{c}0.323 * * * \\
(0.021)\end{array}$ \\
\hline Week with the first Friday of the month & $\begin{array}{c}-0.016^{* * *} \\
(0.004)\end{array}$ & $\begin{array}{c}-0.017 * * * \\
(0.004)\end{array}$ & $\begin{array}{c}-0.060 * * * \\
(0.005)\end{array}$ \\
\hline Monday & $\begin{array}{c}0.229 * * * \\
(0.011)\end{array}$ & $\begin{array}{c}0.272 * * * \\
(0.013)\end{array}$ & $\begin{array}{c}0.460 * * * \\
(0.017)\end{array}$ \\
\hline Tuesday & $\begin{array}{c}0.050 * * * \\
(0.006)\end{array}$ & $\begin{array}{c}0.063 * * * \\
(0.006)\end{array}$ & $\begin{array}{c}0.126 * * * \\
(0.007)\end{array}$ \\
\hline Wednesday & $\begin{array}{c}0.034 * * * \\
(0.005)\end{array}$ & $\begin{array}{c}0.044 * * * \\
(0.005)\end{array}$ & $\begin{array}{c}0.101 * * * \\
(0.006)\end{array}$ \\
\hline Thursday & $\begin{array}{c}0.010^{* *} \\
(0.005)\end{array}$ & $\begin{array}{c}0.016^{* * *} \\
(0.005)\end{array}$ & $\begin{array}{c}0.069 * * * \\
(0.006)\end{array}$ \\
\hline Friday & $\begin{array}{l}-0.002 \\
(0.005)\end{array}$ & $\begin{array}{c}0.001 \\
(0.006)\end{array}$ & $\begin{array}{c}0.054 * * * \\
(0.006)\end{array}$ \\
\hline Observations & 265,565 & 239,248 & 199,355 \\
\hline
\end{tabular}

day. The dependent variable is the log value of catches. All regfessions include boat-owner dummies and a full set of monthyear dummies. All regressions are adjusted for selection into participation according to the Heckman selection model shown in Table 4. 
Appendix Table 3. Structural Participation Probit, Full Set of Estimates (Table 6)

\begin{tabular}{|c|c|c|c|}
\hline & \multicolumn{3}{|c|}{ Dependent variable: Participation } \\
\hline & (1) & (2) & (3) \\
\hline & Base Sample & $\begin{array}{l}\text { More than } 3 \text { days } \\
\text { worked per week }\end{array}$ & $\begin{array}{l}\text { More than } 4 \text { days } \\
\text { worked per week }\end{array}$ \\
\hline Mean Dep. Var. & 0.73 & 0.78 & 0.83 \\
\hline Predicted log(earnings) & $\begin{array}{c}2.072 * * * \\
(0.248)\end{array}$ & $\begin{array}{c}2.262^{* * * * *} \\
(0.366)\end{array}$ & $\begin{array}{c}4.798 * * * \\
(0.853)\end{array}$ \\
\hline $\log$ (Cumulative value of catches within week) & $\begin{array}{c}-0.017 \text { *** } \\
(0.005)\end{array}$ & $\begin{array}{c}-0.047 * * * \\
(0.008)\end{array}$ & $\begin{array}{c}-0.186^{* * *} \\
(0.030)\end{array}$ \\
\hline One consecutive day worked & $\begin{array}{c}0.054 * * * \\
(0.009)\end{array}$ & $\begin{array}{c}-0.043^{* * * *} \\
(0.011)\end{array}$ & $\begin{array}{c}-0.073^{* * * *} \\
(0.018)\end{array}$ \\
\hline Two or more consecutive days worked & $\begin{array}{c}0.054 * * * \\
(0.007)\end{array}$ & $\begin{array}{c}-0.194 * * * \\
(0.009)\end{array}$ & $\begin{array}{c}-0.430^{* * * *} \\
(0.015)\end{array}$ \\
\hline Wind direction Northeast & $\begin{array}{l}-0.009 \\
(0.009)\end{array}$ & $\begin{array}{l}-0.006 \\
(0.011)\end{array}$ & $\begin{array}{c}-0.036 * * * \\
(0.011)\end{array}$ \\
\hline Maximum temperature & $\begin{array}{c}0.004 \\
(0.003)\end{array}$ & $\begin{array}{l}0.006 * * \\
(0.003)\end{array}$ & $\begin{array}{c}0.002 \\
(0.003)\end{array}$ \\
\hline Minimum temperature & $\begin{array}{c}0.018^{* * * *} \\
(0.004)\end{array}$ & $\begin{array}{c}0.014 * * * \\
(0.005)\end{array}$ & $\begin{array}{c}0.021^{* * *} \\
(0.008)\end{array}$ \\
\hline Average wind speed (Km. per hour) & $\begin{array}{l}0.001 * * \\
(0.001)\end{array}$ & $\begin{array}{c}0.003 * * * \\
(0.001)\end{array}$ & $\begin{array}{l}0.003 * * \\
(0.001)\end{array}$ \\
\hline Total Rainfall & $\begin{array}{l}-0.000 \\
(0.000)\end{array}$ & $\begin{array}{c}0.001 \\
(0.001)\end{array}$ & $\begin{array}{l}-0.001 \\
(0.001)\end{array}$ \\
\hline Rainfall duration & $\begin{array}{c}-0.006^{* * * * *} \\
(0.002)\end{array}$ & $\begin{array}{c}-0.011^{* * * *} \\
(0.002)\end{array}$ & $\begin{array}{l}-0.006^{*} \\
(0.003)\end{array}$ \\
\hline Rain dummy & $\begin{array}{c}-0.075 * * * \\
(0.008)\end{array}$ & $\begin{array}{c}-0.071^{* * * *} \\
(0.012)\end{array}$ & $\begin{array}{c}-0.133^{* * * *} \\
(0.023)\end{array}$ \\
\hline Drizzle dummy & $\begin{array}{c}-0.027^{* * * *} \\
(0.010)\end{array}$ & $\begin{array}{c}0.013 \\
(0.011)\end{array}$ & $\begin{array}{c}0.057^{* * * *} \\
(0.016)\end{array}$ \\
\hline First Friday of the month & $\begin{array}{c}-0.740^{* * * * *} \\
(0.016)\end{array}$ & $\begin{array}{c}-0.833^{* * * *} \\
(0.019)\end{array}$ & $\begin{array}{c}-2.161 * * * \\
(0.231)\end{array}$ \\
\hline Holiday dummy & $\begin{array}{c}-0.937^{* * * *} \\
(0.024)\end{array}$ & $\begin{array}{c}-1.033 * * * \\
(0.026)\end{array}$ & $\begin{array}{c}-2.589 * * * \\
(0.281)\end{array}$ \\
\hline Week with the first Friday of the month & $\begin{array}{c}0.087 * * * \\
(0.009)\end{array}$ & $\begin{array}{c}0.144 * * * \\
(0.009)\end{array}$ & $\begin{array}{c}0.476 * * * \\
(0.055)\end{array}$ \\
\hline Monday & $\begin{array}{l}-0.091 \\
(0.066)\end{array}$ & $\begin{array}{c}-0.632^{* * * *} \\
(0.107)\end{array}$ & $\begin{array}{c}-2.644 * * * \\
(0.398)\end{array}$ \\
\hline Tuesday & $\begin{array}{c}-0.098^{* * * *} \\
(0.034)\end{array}$ & $\begin{array}{c}-0.297 * * * \\
(0.040)\end{array}$ & $\begin{array}{c}-0.996 * * * \\
(0.127)\end{array}$ \\
\hline Wednesday & $\begin{array}{c}-0.188^{* * * * *} \\
(0.032)\end{array}$ & $\begin{array}{c}-0.267 * * * \\
(0.036)\end{array}$ & $\begin{array}{c}-0.665^{* * * *} \\
(0.108)\end{array}$ \\
\hline Thursday & $\begin{array}{c}-0.151^{* * * *} \\
(0.030)\end{array}$ & $\begin{array}{c}-0.177^{* * * *} \\
(0.034)\end{array}$ & $\begin{array}{c}-0.531^{* * * *} \\
(0.078)\end{array}$ \\
\hline Friday & $\begin{array}{l}0.064 * * \\
(0.028)\end{array}$ & $\begin{array}{c}0.057 \\
(0.042)\end{array}$ & $\begin{array}{c}-0.183^{* * * *} \\
(0.067)\end{array}$ \\
\hline Monday x Number of family members & $\begin{array}{c}-0.015^{* * * *} \\
(0.006)\end{array}$ & $\begin{array}{l}-0.013 * \\
(0.007)\end{array}$ & $\begin{array}{l}-0.001 \\
(0.008)\end{array}$ \\
\hline Tuesday x Number of family members & $\begin{array}{l}-0.011^{*} \\
(0.006)\end{array}$ & $\begin{array}{l}-0.008 \\
(0.007)\end{array}$ & $\begin{array}{l}-0.000 \\
(0.009)\end{array}$ \\
\hline Wednesday x Number of family members & $\begin{array}{l}-0.002 \\
(0.006)\end{array}$ & $\begin{array}{c}0.005 \\
(0.007)\end{array}$ & $\begin{array}{c}0.001 \\
(0.009)\end{array}$ \\
\hline Thursday x Number of family members & $\begin{array}{l}-0.006 \\
(0.006)\end{array}$ & $\begin{array}{l}-0.003 \\
(0.006)\end{array}$ & $\begin{array}{l}0.001 \\
(0.008)\end{array}$ \\
\hline Friday $x$ Number of family members & $\begin{array}{c}-0.053^{* * *} * \\
(0.005)\end{array}$ & $\begin{array}{c}-0.052^{* * *} \\
(0.008)\end{array}$ & $\begin{array}{c}-0.061^{* * *} \\
(0.008)\end{array}$ \\
\hline Observations & 265,565 & 239,248 & 199,355 \\
\hline
\end{tabular}


Appendix Table 4. Structural Participation Probit, Excluding Cumulative Earnings \& Consecutive Days from the Specification

\begin{tabular}{|c|c|c|}
\hline & (1) & (2) \\
\hline & Baseline Specification ( $\mathrm{Col} 2)$ & $\begin{array}{c}\text { Omitting Cumulative } \\
\text { Earnings \& Consecutive } \\
\text { Days } \\
\end{array}$ \\
\hline Mean Dep. Var. & 0.78 & 0.78 \\
\hline Predicted log(earnings) & $\begin{array}{c}2.262 * * * \\
(0.366)\end{array}$ & $\begin{array}{c}1.971^{* * *} \\
(0.330)\end{array}$ \\
\hline $\log$ (Cumulative value of catches within week) & $\begin{array}{c}-0.047 * * * \\
(0.008)\end{array}$ & \\
\hline One consecutive day worked & $\begin{array}{c}-0.043 * * * \\
(0.011)\end{array}$ & \\
\hline Two or more consecutive days worked & $\begin{array}{l}-0.194 * * * \\
(0.009)\end{array}$ & \\
\hline Weather variables & $<0.001$ & $<0.001$ \\
\hline Day of the week dummies & $<0.001$ & $<0.001$ \\
\hline Month-year dummies & $<0.001$ & $<0.001$ \\
\hline Holiday dummy & $<0.001$ & $<0.001$ \\
\hline Boat owner dumies & $<0.001$ & $<0.001$ \\
\hline Consecutive days worked & $<0.001$ & $<0.001$ \\
\hline Day of the week-family members interactions & $<0.001$ & $<0.001$ \\
\hline Predicted log(earnings) & 0.861 & 0.752 \\
\hline [Mean of Individual Elasticities] & 0.128 & $(0.111)$ \\
\hline $\begin{array}{l}\text { Predicted } \log (\text { earnings }) \\
\text { [Elasticity at Mean Characteristics] }\end{array}$ & $\begin{array}{c}0.795 \\
(0.129)\end{array}$ & $\begin{array}{c}0.694 \\
(0.116)\end{array}$ \\
\hline $\begin{array}{l}\text { Log (Cumulative value of catches within week) } \\
\text { [Elasticity at Mean Characteristics] }\end{array}$ & $\begin{array}{l}-0.017 \\
(0.003)\end{array}$ & \\
\hline Observations & 239,248 & 239,248 \\
\hline
\end{tabular}

Notes: Bootstrap standard errors in parenthesis. The unit of observation is a boat-owner-day. The dependent variable is a dummy that takes value 1 if the boat owner went fishing on a particular day. All regressions include boat owner dummies and a full set of month-year dummies. 